m $\mathrm{mm} \mathbf{m m} \mathrm{m}$

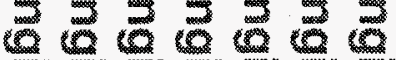

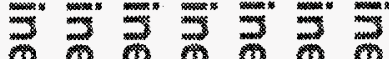
$8 \% 8 \% 8$

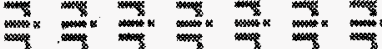

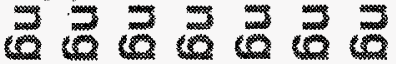
0.90909 $\leq \leq \leq \leq \leq \leq$ के के के के 웅

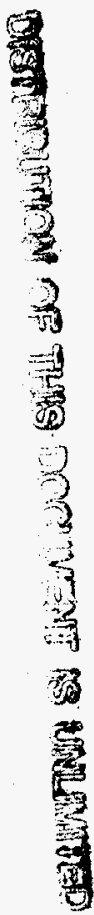

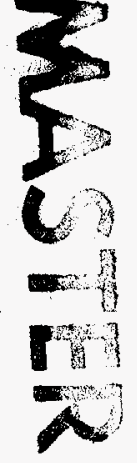

m m m m m m m m m m m m m m m m m m m m

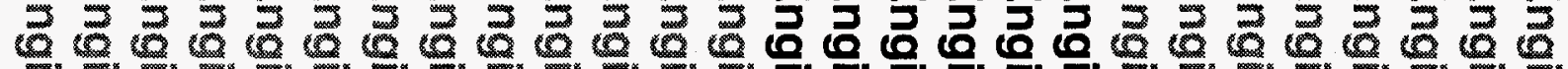
క’

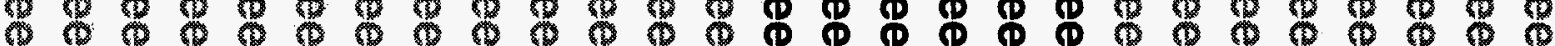

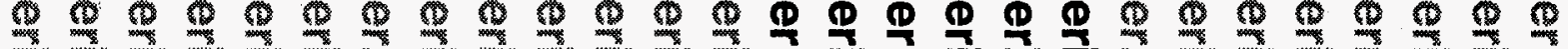

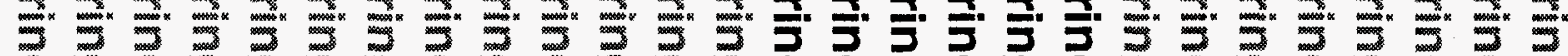

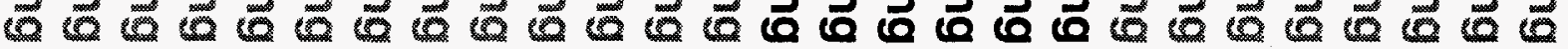

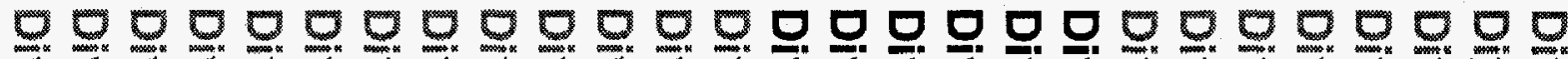

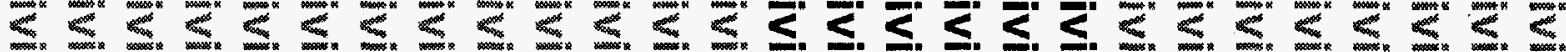

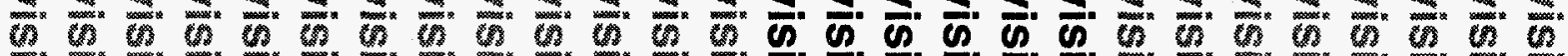

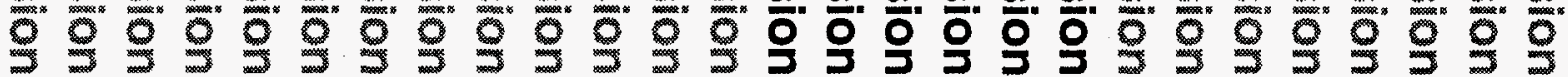
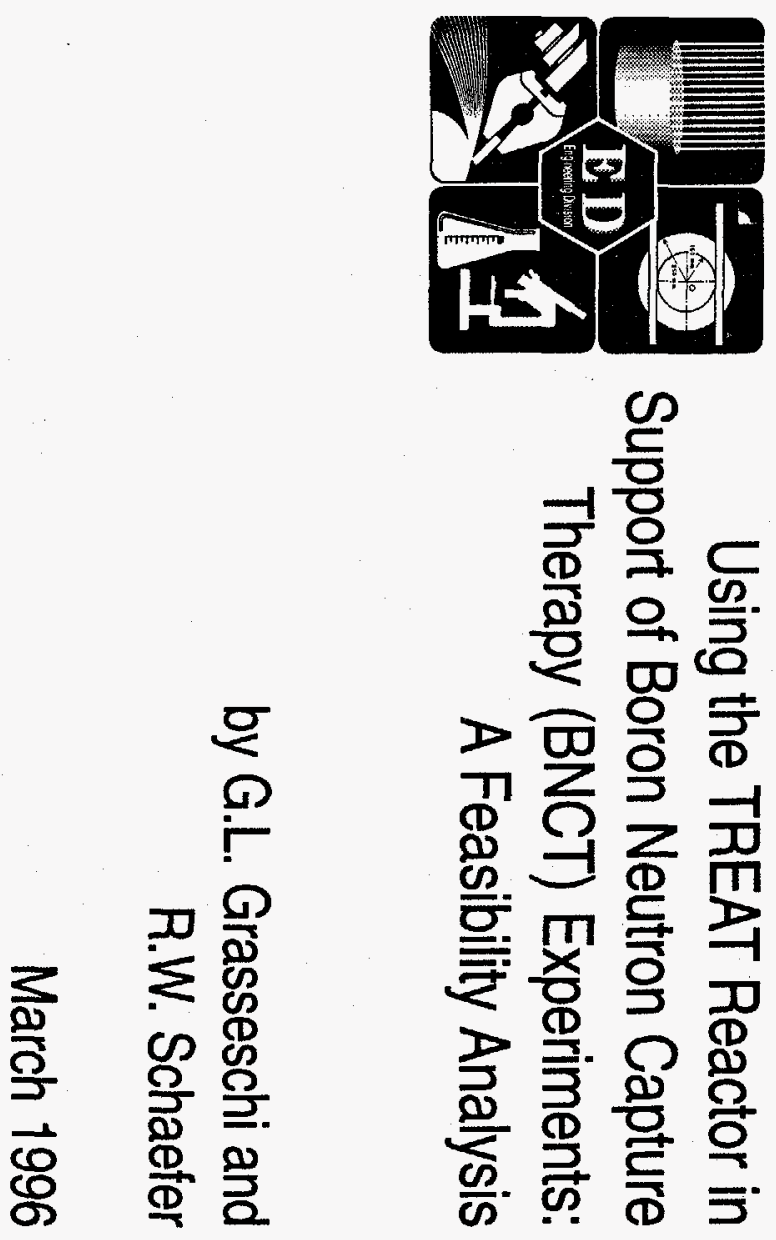

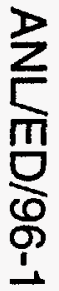




\section{DISCLAIMER}

Portions of this document may be illegible in electronic image products. Images are produced from the best available original document. 
Gary L. Grasseschi and Robert W. Schaefer

Argonne National Laboratory-West

Engineering Division

P.O. Box 2528

Idaho Falls, ID 83403 
Argonne National Laboratory, with facilities in the states of Illinois and Idaho, is owned by the United States government, and operated by The University of Chicago under the provisions of a contract with the Department of Energy.

\section{DISCLAIMER}

This report was prepared as an account of work sponsored by an agency of the United States Government, Neither the United States Government nor any agency thereof, nor any of their employees, makes any warranty, express or implied, or assumes any legal liability or responsibility for the accuracy, completeness, or usefulness of any information, apparatus, product, or process disclosed, or represents that its use would not infringe privately owned rights. Reference herein to any specific commercial product, process, or service by trade name, trademark, manufacturer, or otherwise, does not necessarily constitute or imply its endorsement, recommendation, or favoring by the United States Government or any agency thereof. The views and opinions of authors expressed herein do not necessarily state or reflect those of the United States Government or any agency thereof. 


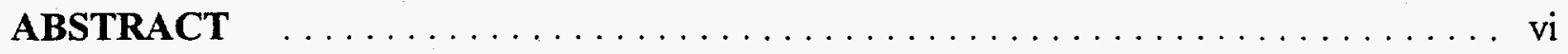

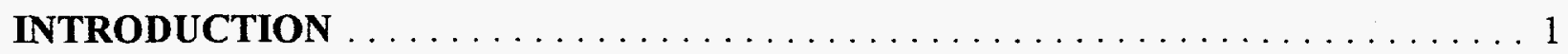

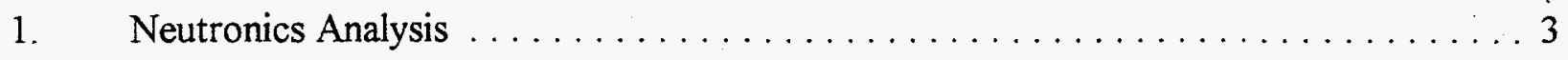

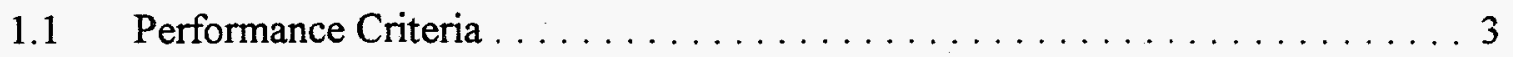

1.2 Models, Data and Computer Codes $\ldots \ldots \ldots \ldots \ldots \ldots \ldots \ldots$

1.3 One-Dimensional Calculations $\ldots \ldots \ldots \ldots \ldots \ldots \ldots \ldots \ldots \ldots \ldots \ldots \ldots \ldots$

1.4 Multidimensional Calculations $\ldots \ldots \ldots \ldots \ldots \ldots \ldots \ldots \ldots$

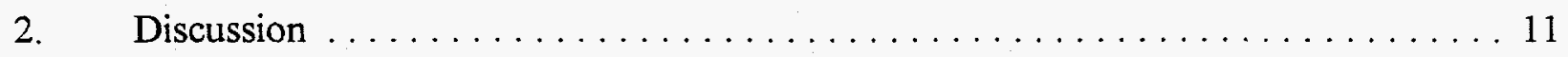

$2.1 \quad$ Neutronics Feasibility $\ldots \ldots \ldots \ldots \ldots \ldots \ldots \ldots \ldots \ldots \ldots \ldots \ldots \ldots$

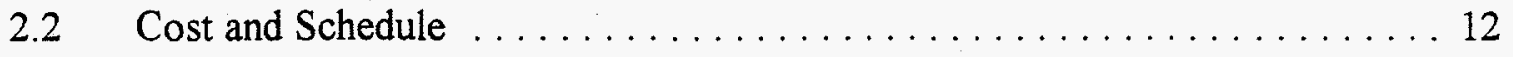

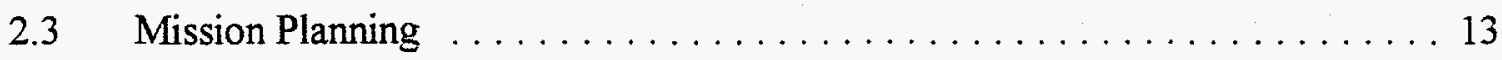

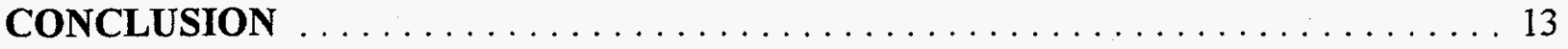

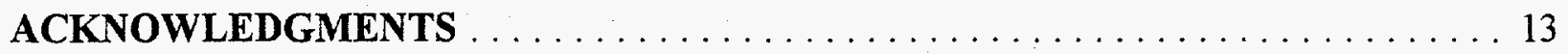

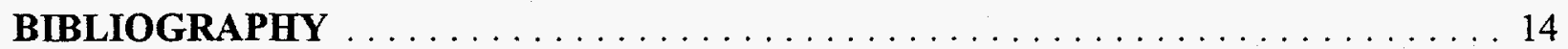




\section{LIST OF TABLES}

\section{Page}

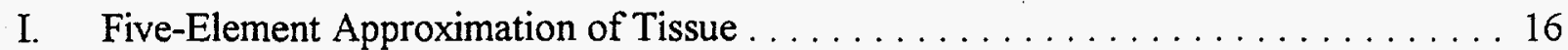

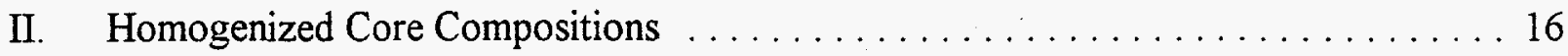

III. Beam Characteristics from Filters for Three Cores; 1-D S12/P3 Solutions $\ldots \ldots \ldots 17$

IV. Moderator Section of Four Filters Used in RZ Calculations $\ldots \ldots \ldots \ldots \ldots \ldots$

V. TREAT Performance Results for Four Filters; S8/P1 RZ Solutions $\ldots \ldots \ldots \ldots 18$ 


\section{LIST OF FIGURES}

\section{Page}

1. RZ Model of TREAT with a BNCT Filter Assembly Replacing East Thermal Column

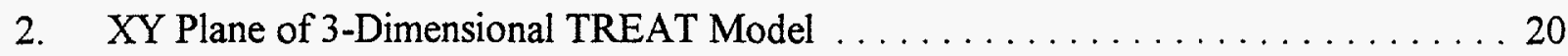

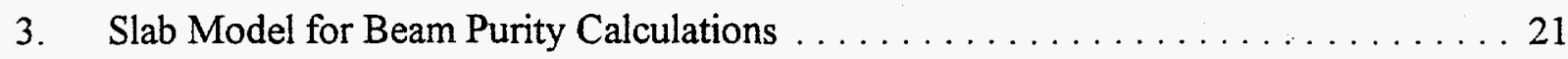

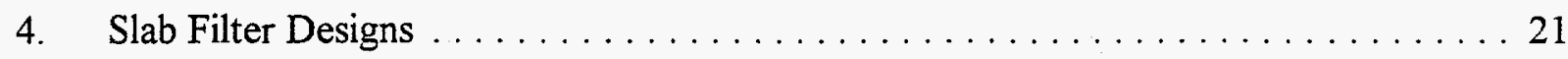

5. Effect of Microscopic Cross Sections on PBF Core Spectrum $\ldots \ldots \ldots \ldots \ldots 22$

6. Core Center Neutron Spectra from TREAT, TRIGA \& PBF $\ldots \ldots \ldots \ldots \ldots \ldots$

7. 302 Filter Entrance Neutron Spectra from TREAT, TRIGA \& PBF . . . . . . . 24

8. 302 Filter Exit Neutron Spectra from TREAT, TRIGA \& PBF $\ldots \ldots \ldots \ldots \ldots 25$

9. 310 Filter Exit Neutron Spectra from TREAT, TRIGA \& PBF $\ldots \ldots \ldots \ldots 26$

10. XY Midplane View: TREAT with BNCT Experiment Replacing East Thermal Column . . . . . . . . . . . . . . . . . . . . . . . . 27

11. TREAT Neutron Spectrum Alteration by Two Filters $\ldots \ldots \ldots \ldots \ldots \ldots \ldots$

12. TREAT Case 4 Flux Attenuation and Spectral Shift $\ldots \ldots \ldots \ldots \ldots \ldots \ldots$

13. Comparison of Reactor-Based Epithermal Neutron Beams $\ldots \ldots \ldots \ldots \ldots$

14. Schedule to Prepare for a TREAT BNCT Mission $\ldots \ldots \ldots \ldots \ldots \ldots \ldots \ldots \ldots$

15. Costs to Prepare for a TREAT BNCT Mission .................... 32 


\title{
USING THE TREAT REACTOR IN SUPPORT OF BORON NEUTRON CAPTURE THERAPY (BNCT) EXPERIMENTS: A FEASIBILITY ANALYSIS
}

by

\author{
Gary L. Grasseschi and Robert W. Schaefer
}

\begin{abstract}
The technical feasibility of using the TREAT reactor facility for boron neutron capture therapy (BNCT) research was assessed. Using one-dimensional neutronics calculations, it was shown that the TREAT core neutron spectrum can be filtered to reduce the undesired radiation (contamination) dose per desired neutron more effectively than can the core spectra from two prominent candidate reactors. Using two-dimensional calculations, it was demonstrated that a non-optimized filter replacing the TREAT thermal column can yield a fluence of desired-energy neutrons more than twice as large as the fluence believed to be required and, at the same time, have a contamination dose per desired neutron almost as low as that from any other candidate facility. The time, effort and cost required to adapt TREAT for a mission supporting BNCT research would be modest.
\end{abstract}




\section{INTRODUCTION}

Boron neutron capture therapy (BNCT) is currently a promising treatment for certain malignancies. Attention is focused particularly on glioblastoma multiforme, a type of brain cancer not amenable to surgery since some of the tumor cells are inextricably intertwined among healthy tissue cells. The advantage of BNCT is that it is able to kill individual tumor cells without excessively damaging neighboring healthy tissue. In this procedure, the patient is infused with boron compounds preferentially absorbed by tumor cells, then is exposed to a neutron beam where the $(n, \alpha)$ reaction in the ${ }^{10} \mathrm{~B}$ isotope provides an energy deposition of about $2.3 \mathrm{MeV}$ of kinetic energy over a distance comparable to the diameter of a cell.

New developments have revived interest in BNCT in the United States. Interest declined when early BNCT trials conducted around 1960 at Brookhaven National Laboratory (BNL) and the Massachusetts Institute of Technology (MIT) were determined to be unsuccessful. [1] Since then, BNCT has been used with some success in Japan. New boron compounds are being developed that concentrate better in tumor cells. Neutron/gamma filters are being used both to reduce radiation damage to healthy tissue and to obviate the need to expose the tumor site surgically. These developments have led to the resumption of experimental human trials at BNL [2] and at MIT. [3] They have also resulted in proposals from several reactors and accelerators in the United States that they be developed into BNCT experiment or treatment facilities.

The purpose of this report is to present a technical feasibility study on using the Transient Reactor Test Facility (TREAT) reactor for BNCT experiment support. TREAT is an air-cooled, graphite moderated (thermal), transient reactor located at Argonne National Laboratory-West in Idaho. It has served fast reactor development for many years irradiating fast reactor test fuels under simulated normal operations and severe-accident conditions, TREAT has a number of features that appear to make it amenable to a BNCT application, including : 1) potential for a very large neutron fluence, deliverable over any time interval of practical interest, 2) ease and economy of facility modification, and 3) ease and economy of operation. 
This feasibility study consists mostly of scoping neutronics analyses. The neutronics question addressed is whether TREAT can be operated to deliver a neutron beam with a high fluence of neutrons in the desired energy epithermal range, with a minimum fluence of neutrons and gamma rays harmful to healthy tissue. The study was conducted by adopting neutron filter designs suggested in the BNCT literature for other reactors; no attempt was made to design an optimum filter for TREAT. The cost and time estimates to modify TREAT are addressed in the concluding section. 


\section{NEUTRONICS ANALYSIS}

\subsection{Performance Criteria}

The success of BNCT depends on whether all the tumor cells can be killed without excessive attendant damage to healthy tissue. Accordingly, performance evaluation requires as a minimum, a measure of the tumor-killing dose and a measure of the healthy-tissue damage dose. Simple, conventional performance measures of dose were deemed most appropriate for a feasibility study.

The epithermal flux level (intensity) to which the patient is exposed is the most common simple measure of tumor-destruction ability cited in the BNCT literature. The epithermal energy range is taken to be $0.5 \mathrm{eV}$ to $10 \mathrm{keV}$, in accordance with the ICRU definition. The basis for this range is that incident neutrons in this energy range are most effective at inducing the ${ }^{10} \mathrm{~B}(\mathrm{n}, \alpha)$ reaction at a typical tumor depth of $2-3 \mathrm{~cm},[4]$ since they thermalize as they penetrate to this depth. In this study, the epithermal range was taken to be $0.4 \mathrm{eV}$ to $15 \mathrm{keV}$, as these boundaries are the closest available in the adopted neutron cross section set.

Epithermal intensity is an appropriate quantity for reactors operating at steady state, as virtually all proposed BNCT reactor facilities other than TREAT are expected to do. An issue for these reactors is whether they can deliver an adequate dose in an acceptably short time. It appears that exposure durations under an hour are considered essential and durations around 10-15 minutes are considered good. Note that beam intensity is an essentially arbitrary quantity for TREAT operating in transient mode; the dose delivered by TREAT is limited by the energy deposited in the core, regardless of whether it occurs in milliseconds or tens of minutes. To put the intensity from TREAT on a comparable basis with that from steady state reactors, the assumption in the following discussion is for a 15 minute, steady state shaped transient, producing a maximum authorized integrated energy of $2.2 \mathrm{GJ}(2.4 \mathrm{MW})$.

Epithermal fluence (flux $\mathrm{x}$ time) was also computed, as an alternative to epithermal intensity. Fluence is a more natural measure for a transient facility, with epithermal fluence most directly related to the beneficial dose delivered to the target. An epithermal fluence of $5 \times 10^{12}$ appears to be about what is needed to destroy a tumor. [1] 
The measure of healthy-tissue damage is a ratio defined by Nigg [5] called beam purity. The numerator of this quantity contains a therapeutically positive attribute, with the harmful components in the denominator. The definition is:

$$
\text { purity }=\frac{(\mathrm{J} / \phi)_{\mathrm{epi}}}{4 \mathrm{k}_{\mathrm{n}} / \phi_{\mathrm{epi}}+\mathrm{k}_{\mathrm{\gamma}} / \phi_{\mathrm{epi}}} \text {, }
$$

where $\mathrm{J}$ is magnitude of the net current vector, $\phi$ is scalar flux, subscript epi indicates the epithermal neutron energy range and $\mathrm{k}$ is a kerma dose rate (integral of flux times kerma factor). The $k_{\gamma}$ is the gamma dose rate from all gamma energies using the five-element approximation of tissue shown in Table I. The $k_{d}$ is the neutron dose rate from all neutron energies above thermal, computed with just the hydrogen kerma at the Table 1 atom density, as recommended by Nigg. [5]. The neutron dose rate is about $6 \%$ higher if all five elements are included.

\subsection{Models, Data, and Computer Codes}

The TREAT reactor is described in detail in Ref. 6 . The TREAT core is constructed from $10.16 \mathrm{~cm}$ square, zircaloy clad elements in a $19 \times 19$ square grid. The elements have chamfered edges, which form coolant air flow channels when the elements are assembled in the grid. The fuel portion of the core grid is $122 \mathrm{~cm}$ long, and about $190 \mathrm{~cm}$ across, with the typical core cross section a square with rounded corners of graphite dummy elements. Fuel elements are composed of reactor grade graphite with 0.009 atom percent finely divided uranium $\left(\mathrm{UO}_{2}\right)$ enriched in ${ }^{235} \mathrm{U}$ to 93 weight percent. The $\mathrm{C}:{ }^{235} \mathrm{U}$ atom ratio is $10000: 1$ resulting in a neutron spectrum that is quite flat in lethergy units, with roughly $1 / 3$ of the neutrons in each of the fast ( $>10 \mathrm{kev}$ ), thermal $(<1 \mathrm{ev})$ and epithermal ranges. The large, dilute core has sufficient heat capacity to allow a transient releasing as much as $2.2 \mathrm{GJ}$ of energy.

Most of the BNCT performance calculations were performed using RZ-geometry models of TREAT, similar to the depiction in Fig. 1. The models include the core surrounded by the graphite reflector and part of the concrete shield. A filter plus collimator extends from the 
core surface to the end of the model along the $\mathrm{Z}$ axis. Filters studied consist of at least three layers: at least $50 \mathrm{~cm}$ of materials to slow fast neutrons into the epithermal range, a thin layer to absorb thermal neutrons (usually $\mathrm{Cd}$ ), and about $10 \mathrm{~cm}$ of material to absorb gamma rays ( $\mathrm{Pb}$ or $\mathrm{Bi}$ ). The radial extent of the filter was varied during the study. A reflective boundary condition was used at the axial midplane to reduce the computation time (implying the presence of two filters). The axial mesh spacing was $4-5 \mathrm{~cm}$ in the interior reflector and core, about $1.7 \mathrm{~cm}$ in the filter and collimator, with the radial mesh spacing $2.5 \mathrm{~cm}$ or smaller to model the conical collimator adequately. The performance parameters were monitored at various axial distances from the core edge through the filter assembly; the values at the exit of the collimator are reported here.

The $\mathrm{RZ}$ models are analogues of the three-dimensional (XYZ) representation of TREAT shown in Fig. 2. The XYZ model was used to design a core loading with nominal excess reactivity, power peaking and control rod worths. These calculations were performed with finite-difference diffusion theory and a 70 group cross section set generated specifically for TREAT. A graphite central reflector region was modelled to shift the neutron flux towards four of the core faces to anticipate an experimental configuration with a beam port at each face. The reactivity effect of replacing the reflector with a filter at one core face was computed to be $1-2$ $\% \Delta \mathrm{k}$.

Because a BNCT filter would be installed along either the $\mathrm{X}$ axis or the $\mathrm{Y}$ axis of the reactor, the $\mathrm{Z}$ axis of the $\mathrm{RZ}$ model is orthogonal to the $\mathrm{Z}$ axis of the $\mathrm{XYZ}$ model. The volumes and the distances to the core face where the filter was placed were preserved for both the internal reflector and the core. Similarly, the reflector and shield thicknesses along the axis of the filter were preserved. All compositions were preserved except that control elements were replaced by fuel elements rather than creating a mix of fuel and control elements in a thin annulus.

The Bugle 80 cross section set [7] was used in all the one- and two-dimensional calculations reported here. While collapsed for a light water reactor concrete shield, Bugle 80 is the most widely used set in the BNCT literature. The set features 47 neutron groups coupled with 20 gamma groups and includes both neutron and gamma kerma factors. The representation of the 
thermal neutron energy range is not very flexible (no explicit upscattering and only two groups below $0.4 \mathrm{eV}$ ), but it allows an adequate prediction of the TREAT neutron spectrum at the energies of interest for filter evaluation. Three isotopes--Cd, $\mathrm{Bi}$ and ${ }^{2} \mathrm{H}$--were copied from the more recent Bugle 93 [8] set and added to the Bugle 80 file.

The TWODANT code [9] was used for all the one- and two-dimensional calculations. The standard $S_{8}$ quadrature set was found to give nearly the same results at the filter exit as the $S_{12}$ set. Similarly, the $P_{1}$ scattering approximation was found to give about the same results ${ }_{3}$ as $P$ scattering. Accordingly, most of the RZ calculations were done with $S_{8}$ and $R_{1}$. The onedimensional calculations were performed with $S_{12}$ and $P_{3}$ as the running time penalty was slight. The spatial mesh for the 1-D calculations was at least as fine as that of the RZ calculations. For all models, the convergence criteria were set to $10^{-5}$ or tighter. Most calculations solved the eigenvalue problem for the full model, but some solved the fixed source problem for just the filter, or just the collimator, by extracting position, angle and energy-dependent boundary sources from previously obtained eigenvalue flux solutions. Epithermal intensity and beam purity were obtained via utility code postprocessing of the TWODANT flux solutions.

\subsection{One-Dimensional Calculations}

The initial RZ calculations were performed with a model where the filter area was limited by the desire to gain access to the core via the hodoscope port, minimizing the effort and cost of the facility modifications by obviating the need to remove any of the TREAT reflector or shielding. The hodoscope access port is a roughly $60 \mathrm{~cm}$ square gap in the north reflector and shield which allows direct observation and radiography of test fuel during irradiation. Initial performance predictions were disappointing, especially for beam purity, with the predicted purity comparable to that of the poorest performers in the published literature and more than a factor of five smaller than that of the best. It was noted that the small cross sectional area of the filter compared to that of the core face provides a significant neutron transport medium, allowing neutrons from the core face radially outward from the filter to enter the filter assembly from the sides. Attempts to shield against the side entry of fast neutrons within the $60 \mathrm{~cm}$ constraint 
proved only marginally effective in improving beam purity. To investigate this and other issues, a series of one-dimensional (slab geometry--effectively radially infinite) calculations were performed.

To test that the TREAT core neutron spectrum is not inherently less well suited for BNCT than the core spectra of alternative reactors, a consistent comparison was made of the beam purity and relative intensity from three different reactors with potential as BNCT facilities-- the Power Burst Facility (PBF), a standard-fuel TRIGA reactor, and TREAT. The remainder of this subsection deals with this study.

A simple calculational approach was used, the slab model shown in Fig. 3 used for each reactor type. No buckling was imposed, with the core thickness adjusted to give an eigenvalue near unity. The reflector had the composition appropriate for each reactor and was effectively infinite. Five different filter designs were tried with each reactor type. The purity and intensity of the beam emitted at the vacuum surface of the filter were computed and compared for the various core and filter options.

The core compositions are given in Table II. The TRIGA composition is for a fuel element cell with $8.5 \mathrm{wt} \% \mathrm{U}$ enriched in ${ }^{235} \mathrm{U}$ to $20 \mathrm{wt} \%(20 / 8.5$ fuel). The TREAT composition is for standard TREAT fuel. The PBF composition was derived from References 10, 11 and 12 . The PBF core was assumed to be made entirely from the $7 \times 7$ canister type with 48 fuel pins and 1 steel pin; the $\mathrm{Al}$ fuel pin spacers were volume averaged.

The filter designs used here are depicted in Fig. 4. The proportions shown there are volume percents. A $15 \mathrm{~cm}$ Bi region is included against the core for the $330 \mathrm{Al} / \mathrm{D}_{2} \mathrm{O}$ filter and optionally for the $302 \mathrm{AlF}_{3} / \mathrm{Al}$ filter. This layer was considered because the PBF configuration described in Ref. 10 has a $\mathrm{Bi}$ "reflector" between the core and the filter. Although labeled there as a reflector, it is viewed here as a filter layer because it has a considerable effect on the beam purity. The $302 \mathrm{AlF}_{3} / \mathrm{Al}$ filter design is the one used in the initial $\mathrm{RZ}$ calculations and came from an early study of BNCT with TREAT. The $310 \mathrm{AlF}_{3} / \mathrm{Al}$ design is an improvement on the 302 design. The $320 \mathrm{Al} / \mathrm{Al}_{2} \mathrm{O}_{3}$ design is similar to a filter proposed for a 20/8.5 fuel TRIGA reactor by Liu.[13] The $\mathrm{Al} / \mathrm{D}_{2} \mathrm{O}$ design is from a PBF description in Ref. 10. Together, these designs provide a broad test bed for evaluating the core spectrum influence on beam purity. 
A basic issue addressed was that an adequate approximation to the core neutron spectrum for each of the reactors be produced with the Bugle 80 cross sections. These cross sections were collapsed with the spectrum in an LWR concrete shield and the actinide cross sections do not account for resonance self shielding or cell heterogeneity. The most serious problem with this occurs in the PBF core, where the infinitely dilute ${ }^{238} \mathrm{U}$ capture cross section causes $\mathrm{k}_{\mathrm{o}}$ to be 0.9 instead of 1.4. To estimate the resulting spectral distortion, two sets of 20 neutron group cross sections were generated with the WIMS code, one based on the PBF fuel pin cell and the other based on the same concrete composition as used for Bugle 80. The asymptotic core spectrum was computed with each of these cross sections and the two results were found to differ little compared to the differences among the spectra of the three cores as computed with Bugle 80 cross sections. As shown in Fig. 5, the PBF core spectra computed with the three cross section sets are similar, and agreement is closest for the two spectra produced with concrete-based cross sections.

Additional confirmation of adequacy was obtained by adjusting the ${ }^{238} \mathrm{U}$ atom density. A search was made for the ${ }^{238} \mathrm{U}$ atom density that, when used with the 20 group concrete spectrum microscopic cross sections, gave the same eigenvalue as when the PBF fuel cell microscopic cross sections were used with the true atom densities. This adjustment corrects the spectrum well except below $0.4 \mathrm{eV}$, which is below the range of interest. Then a beam purity calculation was run twice with Bugle 80 cross sections, once using the true atom density and once using the adjusted atom densities. The beam purity differed by only $3 \%$, evidence that core spectrum distortion caused by using Bugle 80 cross sections is not important for this study.

A compilation of numerical results is given in Table III. The table has five filter types for each of the three cores. Variations in the $J / \phi$ component are negligible and expected since it is not possible to include a collimator in a slab model. The fast neutron dose is the controlling purity component in all cases. For every filter type this component is largest with the TRIGA core and smallest with the TREAT core. Correspondingly, the purity is lowest with the TRIGA core and highest with the TREAT core. This is consistent with the fast flux fraction, which is always highest with the TRIGA core and lowest with the TREAT core. The spread in the purity among core cases is about a factor of two and is as low as $26 \%$ in one case $\left(\mathrm{Al} / \mathrm{D}_{2} \mathrm{O}\right.$ filter). 
Relative intensity values are also given in Table III. It is not possible to compare different cores using the slab model but, for a given core, the relative intensity emerging from different filters can be evaluated. The intensity from the $302 \mathrm{AlF}_{3} / \mathrm{Al}$ filter was arbitrarily set to unity. Although not the point of this exercise, it is clear that some filter designs are better than others from both purity and intensity perspectives. The ranking of filter options on the basis of purity or intensity is virtually the same for all cores, another indication that the core spectrum, while significant, does not make a vast difference.

Figures 6 through 9 are comparisons of neutron spectra from the three reactors. Fig. 6 shows that the core center spectrum is flattest in TREAT, the thermal component is smallest in PBF and the component above $1 \mathrm{MeV}$ is about the same in TRIGA and PBF. Comparing Figures 6 and 7 , note that the spectra at the filter entrance have somewhat lower values at the energy extremes but the spectra are similar to those at core center. The spectra emerging from two of the filter types are shown in Figures 8 and 9. Both filter types are seen to be very effective in producing spectra predominantly in the epithermal range. The residual flux in the high energy tail is largest for TRIGA and smallest for TREAT, in accordance with the fast neutron dose and beam purity results.

\subsection{Multidimensional Calculations}

With it apparent that virtually all of the neutrons from a core face would need be passed through a moderator or shielded, the next easiest access to the core is at the thermal column on the east side of the reactor. Here, an entire core face can be readily exposed by withdrawing shield plugs and removing the thermal column graphite. Figure 10 shows a conceptual filter and collimator occupying this east face thermal column access port; the results reported below are based upon this arrangement. The effect of extending the filter further to span also the entire reflector width at this face was explored but little performance advantage was observed. Note that the transient and control/shutdown rods banks have been interchanged. 
$\mathrm{RZ}$ calculations were run for four similar filter designs. The same collimator was used in each case, approximating a cone with a diameter stepping down $10 \mathrm{~cm}$ for every axial $10 \mathrm{~cm}$ distance. The inner diameter of the cone is $125 \mathrm{~cm}$ at the filter exit and $20 \mathrm{~cm}$ at the collimator aperture. There are two radial annuli, an inner thermal neutron absorbing liner of $2.5 \mathrm{~cm}, 5 \%$ density $\mathrm{LiF}$, and a $20 \mathrm{~cm}$-thick wall of $\mathrm{Bi}$. Likewise, all the filters have their three outermost axial layers in common: a $2 \mathrm{~cm}$-thick layer of $1 \%$ density $\mathrm{LiF}$ at the filter exit, preceded by a 9 $\mathrm{cm}$-thick layer of $\mathrm{Bi}$, preceded by a $1 \mathrm{~cm}$-thick layer of $5 \%$ density $\mathrm{Cd}$. The filters differ only in the material or materials used in the $65 \mathrm{~cm}$-thick neutron moderating section. These are described in Table IV. All the filter layers are $152 \mathrm{~cm}$ in diameter, shielded from side contamination by a radial layer of $\mathrm{Bi} 20 \mathrm{~cm}$ thick .

The performance results for these four cases are given in Table V. In all cases, the beam purity is acceptable and the epithermal fluence (or intensity) is quite a bit greater than appears to be necessary. The substantial range of performance results show the sensitivity to filter design. For example, changing the proportions of $\mathrm{Al}$ and $\mathrm{Al}_{2} \mathrm{O}_{3}$ (Cases 1 and 2) increases the intensity by $70 \%$ while decreasing the purity by less than $1 \%$. There is clearly a large potential to make substantial improvements in performance via optimization in filter design.

Three normalized neutron spectra, demonstrating the effectivness of the filters are compared in Fig. 11. The relatively flat profile is the core center spectrum, the other two taken from the exit of the collimator in Cases 2 and 4 . The spectral shift and attenuation due to a filter assembly (Case 4) is shown in Fig. 12. The roughly 2 decade drop near the $10 \mathrm{Kev}$ epithermal boundary is evident and commensurate with that of Figures 8 and 9. The attenuation in the total epithermal flux through the filters due to cross section, and the geometric attenuation through the collimator to the beam aperture were consistently calculated to be on the order of 1 decade each.

In Fig. 13, the Case 4 results are compared with the performance of other reactor facilities, as compiled by Nigg [5]. The TREAT intensity is significantly higher than that from any other reactor, and the TREAT purity value is within $10 \%$ of the highest value. It seems clear from the sensitivity demonstrated in Table $\mathrm{V}$ that the beam purity from TREAT could be improved much more than $10 \%$ while maintaining a high intensity. Thus, the BNCT performance potential of TREAT is at least competitive with that of the best of the candidate reactor facilities. 


\section{DISCUSSION}

\subsection{Neutronics Feasibility}

This study has shown that the TREAT reactor is capable of producing a beam for BNCT whose performance characteristics are at least as good as those of eight other reactors that have been studied for this application. Without any attempt at filter optimization, the TREAT beam purity is within $10 \%$ of the best value in the literature and the maximum beam fluence is far more than seems to be required. This fluence can be delivered over essentially any time history that may be desired, a unique feature among candidate facilities.

It was determined, using one-dimensional calculations, that the core neutron spectrum of TREAT offers a modest advantage in producing a high purity beam. Consistent calculations compared TREAT, PBF and TRIGA reactors using five different filters. In every case, the TREAT reactor produced the highest beam purity. Only the 20/8.5 TRIGA fuel was tested but it seems unlikely that using another TRIGA fuel, e.g., 20/45 fuel, would alter the hierarchy. Although purity variations among the reactors differed by as much as a factor of two, this advantage is of only modest importance because differences in filter design can produce much larger changes.

The excess fluence capability of TREAT allows flexibility in operation and design. The energy of the transient could be reduced, which would allow a significant reduction in the cooldown time required between maximum energy transients (about 4 hours, the cooldown time roughly proportional to the total energy deposited). Alternatively, in a design optimization, fluence could be traded off for improvements in beam purity--increasing the forward directed component of the beam (larger $\mathrm{J} / \phi$ ) and decreasing the contamination doses.

The TREAT performance could almost certainly be improved significantly by optimizing the filter design. One obvious issue to address is a core flux tilt away from the filter due mostly to a hardening of the spectrum near the core edge. It may be possible to put a material at the core-filter interface that would reduce this tilt and increase the beam fluence. The geometry of the core, in particular that of the central reflector could also be altered to shift power towards 
the interface. Within the neutron moderating section of the filter, there are many choices of material type, sequence and thickness. As the filter alternatives that have been calculated so far show (see for example Table III and Figures 8 and 9), these choices can have a large impact upon epithermal intensity and beam purity. Collimation of the beam from TREAT is an area that has received almost no attention so far. It is anticipated that it would be possible, with alternative geometry and materials, to increase the forward directed component of the beam without an inordinate sacrifice in intensity.

One caveat is that the beam purity measure used here was chosen because it is simple and has been used in the literature to compare the merits of different reactors and filters. Although it brings together into one quantity all the parameters of interest--the forward directed component, and the neutron and gamma ray damage doses per epithermal neutron--it is not clear that it accounts appropriately for the relative importance of these quantities. One observation is that all the neutrons in the epithermal range are given equal importance whereas neutrons at the high end of the range (8-10 Kev) are actually more effective than those at the low end. [5] Examination of Figures 8 and 9 with this in mind suggests that the true beam purity advantage offered by TREAT is likely less than the simple purity measure would indicate for some experiments or treatment protocols.

\subsection{Cost and Schedule}

Having established the neutronics feasibility, questions of cost and schedule for making TREAT functional as a BNCT facility become relevant. Note that TREAT has no water tank or pressure barrier, has easy access to the core and is above grade, making the necessary modifications relatively simple. Note also that there is no fuel cycle associated with the reactor operating in transient mode, with attendant long term savings of cost and a simplified regulatory environment. The reactor is in good condition, due in part to a recent control system upgrade.

Preliminary cost and schedule estimates have been made assuming that an aluminum/aluminum oxide filter would replace the thermal column [14]. The schedule, shown in Fig. 14, indicates that the analysis, modifications to the facility, modifications to documents 
for safety and operations, and personnel training would take about six months to complete. The cost estimates for this work, shown in Fig. 15, total to just over one million dollars. The cost for operating TREAT in a program dedicated to the support of BNCT experiments would be approximately two million dollars per year. [15]

\subsection{Mission Planning}

Given the established flexibility in varying the core loading, the space available at the thermal column access port, and the ability to deliver an intense epithermal neutron beam at distances in the range of 1-2 meters from the core face, among the experiments might be:

- the testing of competitive filter designs

- the testing of beam collimation geometry and materials

- investigations into treatment rate effects and optimum fractions

- the testing of filter assembly detectors and instrumentation

- the development of control and data aquisition software

- investigations into the potential for designing and using graphite moderated, gas cooled, transient reactors as dedicated patient treatment facilities.

\section{CONCLUSION}

TREAT has long served as one of the tools in the research efforts of Argonne National Laboratory. The facility is currently available for a new kind of mission. It is not envisioned that TREAT would be used as a production-type patient irradiation facility. [16] It has been shown here, however, that a role in support of BNCT experiments is technically feasible, cost effective. and that the facility is uniquely suited for experiments supporting BNCT research and development.

\section{ACKNOWLEDGMENTS}

The authors gratefully acknowlege the contribution of Thomas R. Hubbard, University of Virginia, for his assistance in much of the early modelling, software development and analysis during the summer of 1995 . 


\section{BIBLIOGRAPHY}

1. R. F. Barth, A. H. Soloway and R. G. Fairchild, "Boron Neutron Capture Therapy of Cancer," Cancer Research, 50, 1061 (1990).

2. J. Capala et al., "The BNCT Treatment Planning for the Brookhaven Trials on Human Gliomas," Trans. Am. Nucl. Soc., 73, 21 (1995).

3. O. K. Harling et al., "Initiation of a Phase-I Trial of Neutron Capture Therapy at the MIT Research Reactor," Trans. Am. Nucl. Soc., 73, 22 (1995).

4. W. A. Neuman and J. L. Jones, "Conceptual Design of a Medical Reactor for Neutron Capture Therapy," Nuclear Technology, 92, 77 (1990).

5. D. W. Nigg, Lockheed Martin Idaho Technologies, Personal Communication, July 19, 1995.

6. F. Kirn et al., "Reactor Physics Measurements in TREAT," ANL-6174, Argonne National Laboratory (1960).

7. R. W. Roussin, "BUGLE-80, Coupled 47-Neutron, 20-Gamma Ray, $\mathrm{P}_{3}$, Cross-Section Library for LWR Shielding Calculations," DLC-75, Radiation Shielding Information Center, Oak Ridge National Laboratory (1980).

8. D. T. Ingersoll, et al., "BUGLE-93, Coupled 47 Neutron, 20 Gamma-Ray Group CrossSection Library Derived From ENDF/B-VI for LWR Shielding and Pressure Vessel Dosimetry Applications," DLC-175, Radiation Shielding Information Center, Oak Ridge National Laboratory (1994).

9. R. E. Alcouffe, et al, "User's Guide for TWODANT: A Code Package for TwoDimensional, Diffusion-Accelerated, Neutral-Particle Transport," LA-10049-M, Los Alamos National Laboratory (1990).

10. F. J. Wheeler, et al., "Epithermal Neutron Beam Design for Neutron Capture Therapy at the Power Burst Facility and the Brookhaven Medical Research Reactor," Nuclear Technology, 92, 106 (1990).

11. D. W. Nigg and A. J. Scott, "Computed Reactivity Requirements and Control Rod Worth for 30-MW, 2-Day Operation of PBF With a Large Reactive Experiment," TREENUREG-1024, EG\&G Idaho, Inc. (1976).

12. B. L. Rushton and W. R. Carpenter, "Methods Used for Physics Analysis of the Power Burst Facility and Computed Results for the Design Core," ANCR-1008, Aerojet Nuclear Company (1971). 
13. H. B. Liu, "Design of Neutron Beams for Neutron Capture Therapy Using a 300-kW Slab TRIGA Reactor," Nuclear Technology, 109, 314 (1995).

14. B. G. Harris, Argonne National Laboratory, Personal Communication, October, 1995.

15. R. W. Swanson, Argonne National Laboratory, Personal Communication, October, 1995.

16. J. I. Sackett, Argonne National Laboratory, Personal Communication, November, 1995. 
TABLE I. Five-Element Approximation of Tissue

\begin{tabular}{|l|l|}
\hline Isotope & Atom Density (atoms/bam-cm) \\
\hline $\mathrm{H}$ & 0.06011000 \\
\hline $\mathrm{C}$ & 0.01153000 \\
\hline $\mathrm{N}$ & 0.00111800 \\
\hline $\mathrm{O}$ & 0.02296000 \\
\hline $\mathrm{Cl}$ & 0.00003397 \\
\hline
\end{tabular}

TABLE II. Homogenized Core Compositions

\begin{tabular}{|l|l|l|l|}
\hline Isotope & TRIGA & PBF & TREAT \\
\hline $\mathrm{H}$ & 0.0568420 & 0.0176390 & 0.0 \\
\hline $\mathrm{B}-10$ & 0.0 & 0.0 & 0.0000002 \\
\hline $\mathrm{C}$ & 0.0 & 0.0 & 0.0762014 \\
\hline $\mathrm{O}$ & 0.0108860 & 0.0320290 & 0.0000165 \\
\hline $\mathrm{Mg}$ & 0.0 & 0.0000640 & 0.0 \\
\hline $\mathrm{Al}$ & 0.0 & 0.0059330 & 0.0 \\
\hline $\mathrm{Si}$ & 0.0000301 & 0.0000330 & 0.0 \\
\hline $\mathrm{Ca}$ & 0.0 & 0.0022920 & 0.0 \\
\hline $\mathrm{Cr}$ & 0.0006360 & 0.0018310 & 0.0 \\
\hline $\mathrm{Mn}$ & 0.0000320 & 0.0001820 & 0.0 \\
\hline $\mathrm{Fe}$ & 0.0021870 & 0.0061790 & 0.0000144 \\
\hline $\mathrm{Ni}$ & 0.0002750 & 0.0008510 & 0.0 \\
\hline $\mathrm{Zr}$ & 0.0222860 & 0.0089890 & 0.0009861 \\
\hline $\mathrm{U}-235$ & 0.0001540 & 0.0002610 & 0.0000077 \\
\hline $\mathrm{U}-238$ & 0.0006190 & 0.0011470 & 0.0000006 \\
\hline & & & \\
\hline
\end{tabular}


TABLE III. Beam Characteristics From Filters For Three Cores; 1-D S12/P3 Solutions

\begin{tabular}{|c|c|c|c|c|c|c|c|c|c|c|}
\hline $\begin{array}{l}\text { Filter } \\
\text { Design } 1\end{array}$ & Reactor & $\begin{array}{l}\text { Current } \\
\text { / Flux }\end{array}$ & $\begin{array}{l}\text { Neutron } \\
\text { Dose } 2\end{array}$ & $\begin{array}{l}\text { Gamma } \\
\text { Dose }\end{array}$ & $\begin{array}{l}\text { Beam } \\
\text { Purity } \\
\text { Absolute }\end{array}$ & $\begin{array}{l}\text { Beam } \\
\text { Purity } \\
\text { Relative }\end{array}$ & $\begin{array}{l}\text { Relative } \\
\text { Intensity }\end{array}$ & $\begin{array}{l}\text { Flux } \\
\text { Fraction } \\
\text { Fast }\end{array}$ & $\begin{array}{l}\text { Flux } \\
\text { Fraction } \\
\text { Epithml }\end{array}$ & $\begin{array}{l}\text { Flux } \\
\text { Fraction } \\
\text { Thermal }\end{array}$ \\
\hline 302 & TRIGA & 0.598 & $6.70 \mathrm{E}-11$ & $3.90 \mathrm{E}-12$ & $2.29 E+09$ & 1.00 & 1.00 & 0.054 & 0.946 & 0.000 \\
\hline $\mathrm{AlF}_{3}+\mathrm{Al}$ & PBF & 0.599 & $5.66 \mathrm{E}-11$ & $3.39 \mathrm{E}-12$ & $2.60 \mathrm{E}+09$ & 1.18 & 1.00 & 0.046 & 0.954 & 0.000 \\
\hline no $B i$ & TREAT & 0.602 & $3.68 \mathrm{E}-11$ & 3.63E-12 & $3.99 E+09$ & 1.81 & 1.00 & 0.027 & 0.973 & 0.000 \\
\hline 302 & TRIGA & 0.600 & $3.31 \mathrm{E}-11$ & 2.62E-12 & $4.44 E+09$ & 1.00 & 0.69 & 0.024 & 0.976 & 0.000 \\
\hline $\mathrm{AlF}_{3}+\mathrm{Al}$ & PBF & 0.601 & $2.95 \mathrm{E}-11$ & $2.50 \mathrm{E}-12$ & $4.99 E+09$ & 1.12 & 0.73 & 0.021 & 0.979 & 0.000 \\
\hline w Bi & TREAT & 0.602 & $2.28 \mathrm{E}-11$ & $3.01 \mathrm{E}-12$ & $6.39 E+09$ & 1.44 & 0.93 & 0.015 & 0.985 & 0.000 \\
\hline 310 & TRIGA & 0.582 & $3.42 \mathrm{E}-11$ & $6.18 \mathrm{E}-12$ & $4.07 \mathrm{E}+09$ & 1.00 & 3.01 & 0.027 & 0.973 & 0.000 \\
\hline $\mathrm{AlF}_{3}+\mathrm{Al}$ & PBF & 0.582 & $2.80 \mathrm{E}-11$ & $5.30 \mathrm{E}-12$ & $4.96 \mathrm{E}+09$ & 1.22 & 3.10 & 0.023 & 0.977 & 0.000 \\
\hline & TREAT & 0.583 & $1.51 \mathrm{E}-11$ & $6.72 \mathrm{E}-12$ & $8.68 E+09$ & 2.13 & 3.72 & 0.011 & 0.989 & 0.000 \\
\hline 320 & TRIGA & 0.584 & $1.71 \mathrm{E}-11$ & 7.10E-12 & $7.72 E+09$ & 1.00 & 0.93 & 0.014 & 0.986 & 0.000 \\
\hline $\mathrm{Al}+\mathrm{Al}_{2} \mathrm{O}_{3}$ & PBF & 0.584 & $1.34 \mathrm{E}-11$ & $6.49 \mathrm{E}-12$ & $9.69 E+09$ & 1.26 & 0.88 & 0.011 & 0.989 & 0.000 \\
\hline & TREAT & 0.584 & $6.91 \mathrm{E}-12$ & $8.95 \mathrm{E}-12$ & $1.60 \mathrm{E}+10$ & 2.07 & 1.19 & 0.005 & 0.995 & 0.000 \\
\hline 330 & TRIGA & 0.579 & $1.03 \mathrm{E}-11$ & $8.11 \mathrm{E}-12$ & $1.17 \mathrm{E}+10$ & 1.00 & 1.46 & 0.018 & 0.976 & 0.006 \\
\hline $\mathrm{AlD}_{2} \mathrm{O}$ & PBF & 0.579 & $9.64 \mathrm{E}-12$ & $7.71 \mathrm{E}-12$ & $1.25 \mathrm{E}+10$ & 1.07 & 1.58 & 0.017 & 0.977 & 0.006 \\
\hline w Bi & TREAT & 0.579 & $7.37 \mathrm{E}-12$ & $9.88 \mathrm{E}-12$ & $1.47 \mathrm{E}+10$ & 1.26 & 2.27 & 0.013 & 0.981 & 0.007 \\
\hline
\end{tabular}

1 Filter Designs from Figure 4.

2 Dose - cGy/epithermal neutron

Relative purity compares the three reactor types for a given filter

Relative intensity compares filter types for a given reactor 
TABLE III. Beam Characteristics From Filters For Three Cores; 1-D S12/P3 Solutions

\begin{tabular}{|c|c|c|c|c|c|c|c|c|c|c|}
\hline $\begin{array}{l}\text { Filter } \\
\text { Design } 1\end{array}$ & Reactor & $\begin{array}{l}\text { Current } \\
\text { / Flux }\end{array}$ & $\begin{array}{l}\text { Neutron } \\
\text { Dose } 2\end{array}$ & $\begin{array}{l}\text { Gamma } \\
\text { Dose }\end{array}$ & $\begin{array}{l}\text { Beam } \\
\text { Purity } \\
\text { Absolute }\end{array}$ & $\begin{array}{l}\text { Beam } \\
\text { Purity } \\
\text { Relative }\end{array}$ & $\begin{array}{l}\text { Relative } \\
\text { Intensity }\end{array}$ & $\begin{array}{l}\text { Flux } \\
\text { Fraction } \\
\text { Fast }\end{array}$ & $\begin{array}{l}\text { Flux } \\
\text { Fraction } \\
\text { Epithml }\end{array}$ & $\begin{array}{l}\text { Flux } \\
\text { Fraction } \\
\text { Thermal }\end{array}$ \\
\hline 302 & TRIGA & 0.598 & $6.70 \mathrm{E}-11$ & $3.90 \mathrm{E}-12$ & $2.29 \mathrm{E}+09$ & 1.00 & 1.00 & 0.054 & 0.946 & 0.000 \\
\hline $\mathrm{AlF}_{3}+\mathrm{Al}$ & PBF & 0.599 & $5.66 \mathrm{E}-11$ & $3.39 \mathrm{E}-12$ & $2.60 \mathrm{E}+09$ & 1.18 & 1.00 & 0.046 & 0.954 & 0.000 \\
\hline no $\mathrm{Bi}$ & TREAT & 0.602 & $3.68 \mathrm{E}-11$ & $3.63 \mathrm{E}-12$ & $3.99 \mathrm{E}+09$ & 1.81 & 1.00 & 0.027 & 0.973 & 0.000 \\
\hline 302 & TRIGA & 0.600 & $3.31 \mathrm{E}-11$ & $2.62 \mathrm{E}-12$ & $4.44 \mathrm{E}+09$ & 1.00 & 0.69 & 0.024 & 0.976 & 0.000 \\
\hline $\mathrm{AlF}_{3}+\mathrm{Al}$ & PBF & 0.601 & $2.95 \mathrm{E}-11$ & $2.50 \mathrm{E}-12$ & $4.99 \mathrm{E}+09$ & 1.12 & 0.73 & 0.021 & 0.979 & 0.000 \\
\hline w Bi & TREAT & 0.602 & $2.28 \mathrm{E}-11$ & $3.01 \mathrm{E}-12$ & $6.39 \mathrm{E}+09$ & 1.44 & 0.93 & 0.015 & 0.985 & 0.000 \\
\hline 310 & TRIGA & 0.582 & 3.42E-11 & $6.18 \mathrm{E}-12$ & $4.07 \mathrm{E}+09$ & 1.00 & 3.01 & 0.027 & 0.973 & 0.000 \\
\hline $\mathrm{AlF}_{3}+\mathrm{Al}$ & PBF & 0.582 & $2.80 \mathrm{E}-11$ & $5.30 \mathrm{E}-12$ & $4.96 \mathrm{E}+09$ & 1.22 & 3.10 & 0.023 & 0.977 & 0.000 \\
\hline & TREAT & 0.583 & $1.51 \mathrm{E}-11$ & $6.72 \mathrm{E}-12$ & $8.68 \mathrm{E}+09$ & 2.13 & 3.72 & 0.011 & 0.989 & 0.000 \\
\hline 320 & TRIGA & 0.584 & $1.71 \mathrm{E}-11$ & $7.10 \mathrm{E}-12$ & $7.72 \mathrm{E}+09$ & 1.00 & 0.93 & 0.014 & 0.986 & 0.000 \\
\hline $\mathrm{Al}+\mathrm{Al}_{2} \mathrm{O}_{3}$ & PBF & 0.584 & $1.34 \mathrm{E}-11$ & $6.49 \mathrm{E}-12$ & $9.69 \mathrm{E}+09$ & 1.26 & 0.88 & 0.011 & 0.989 & 0.000 \\
\hline & TREAT & 0.584 & $6.91 \mathrm{E}-12$ & $8.95 \mathrm{E}-12$ & $1.60 \mathrm{E}+10$ & 2.07 & 1.19 & 0.005 & 0.995 & 0.000 \\
\hline 330 & TRIGA & 0.579 & $1.03 \mathrm{E}-11$ & $8.11 \mathrm{E}-12$ & $1.17 \mathrm{E}+10$ & 1.00 & 1.46 & 0.018 & 0.976 & 0.006 \\
\hline $\mathrm{AlD}_{2} \mathrm{O}$ & PBF & 0.579 & $9.64 \mathrm{E}-12$ & $7.71 \mathrm{E}-12$ & $1.25 \mathrm{E}+10$ & 1.07 & 1.58 & 0.017 & 0.977 & 0.006 \\
\hline w Bi & TREAT & 0.579 & $7.37 \mathrm{E}-12$ & $9.88 \mathrm{E}-12$ & $1.47 E+10$ & 1.26 & 2.27 & 0.013 & 0.981 & 0.007 \\
\hline
\end{tabular}

1 Filter Designs from Figure 4.

2 Dose - cGy/epithermal neutron

Relative purity compares the three reactor types for a given filter

Relative intensity compares filter types for a given reactor 


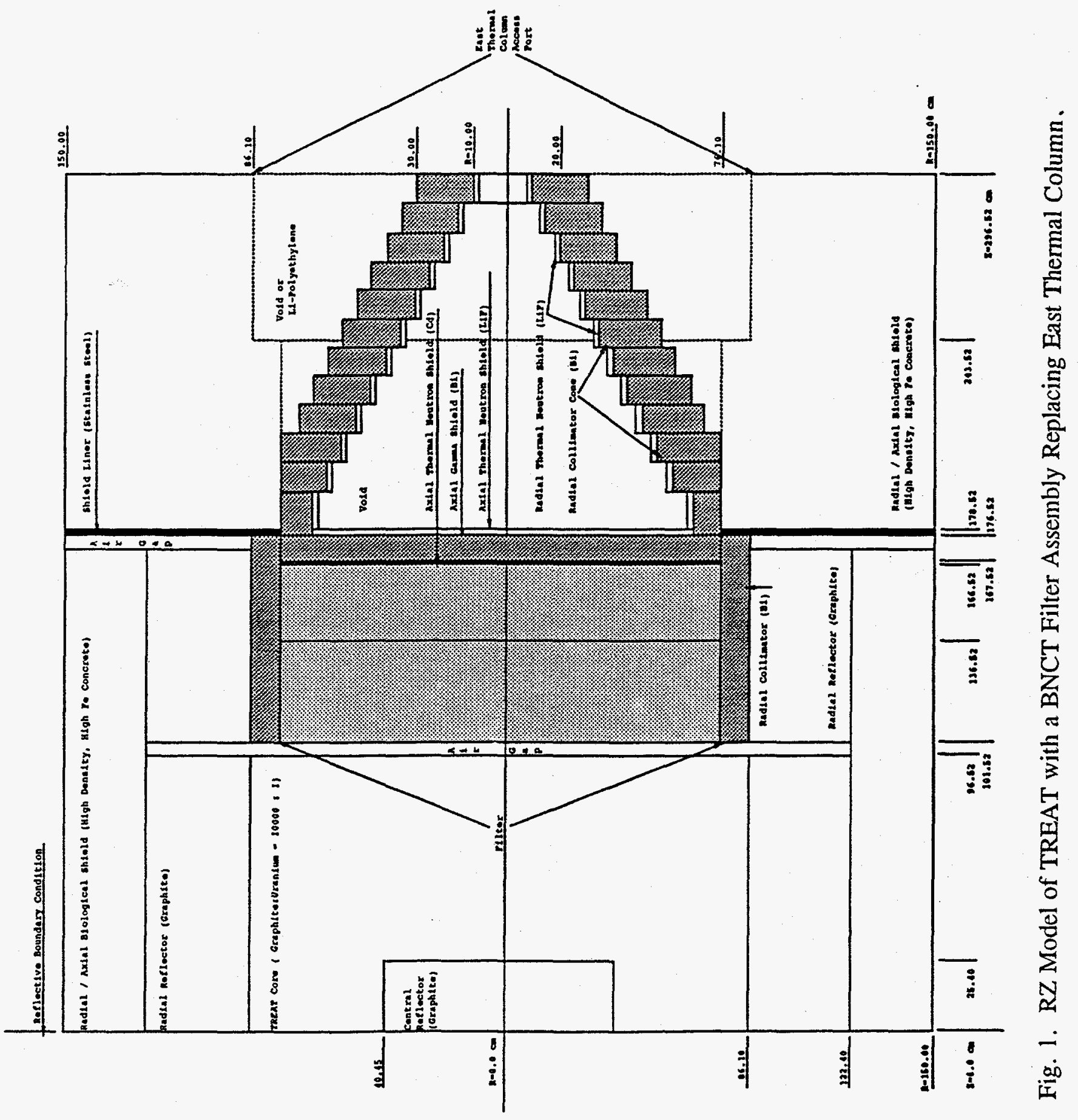




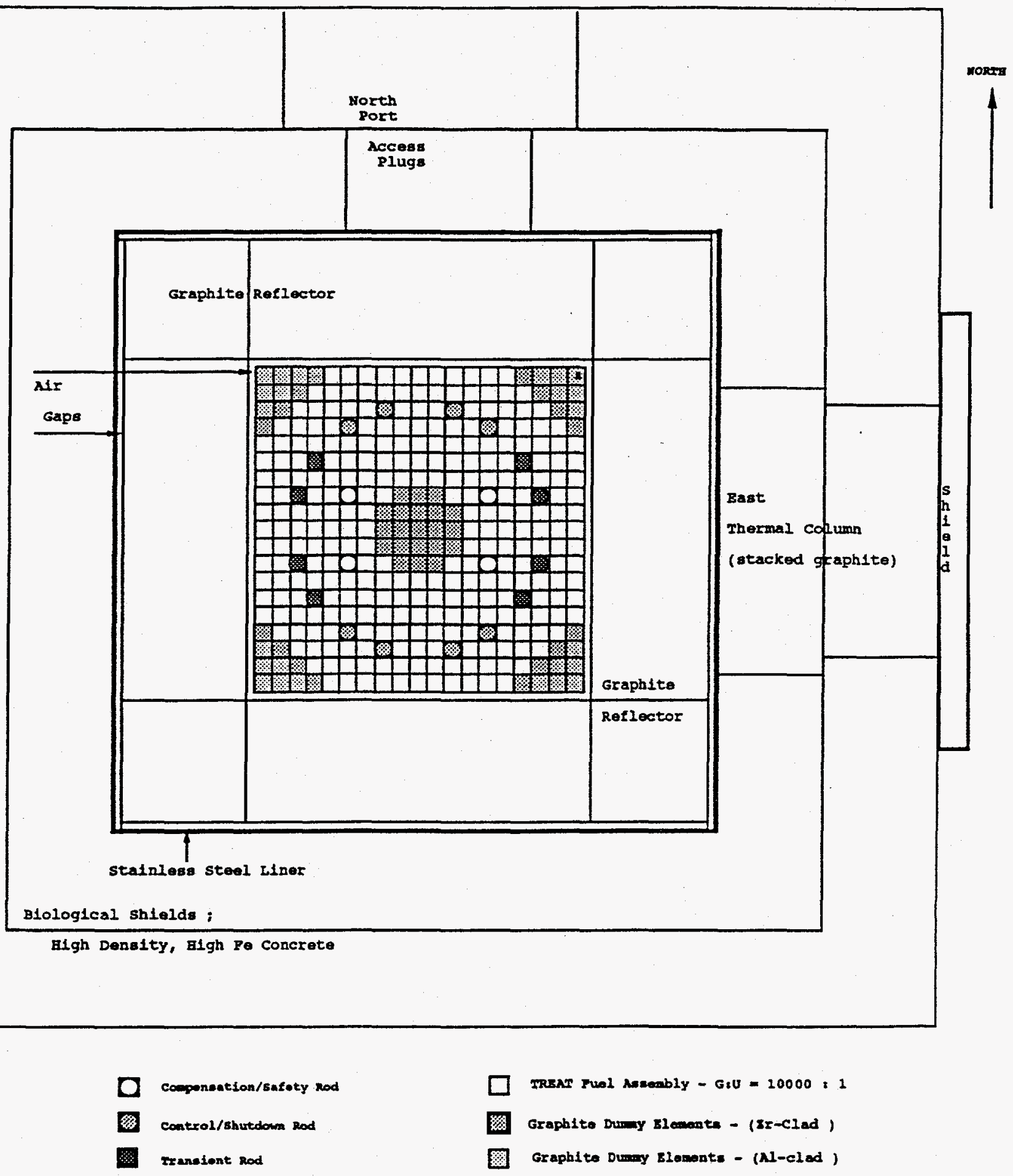

Fig. 2. XY Plane of 3-Dimensional TREAT Model. 
Fig. 3. Slab Model for Beam Purity Calculations.

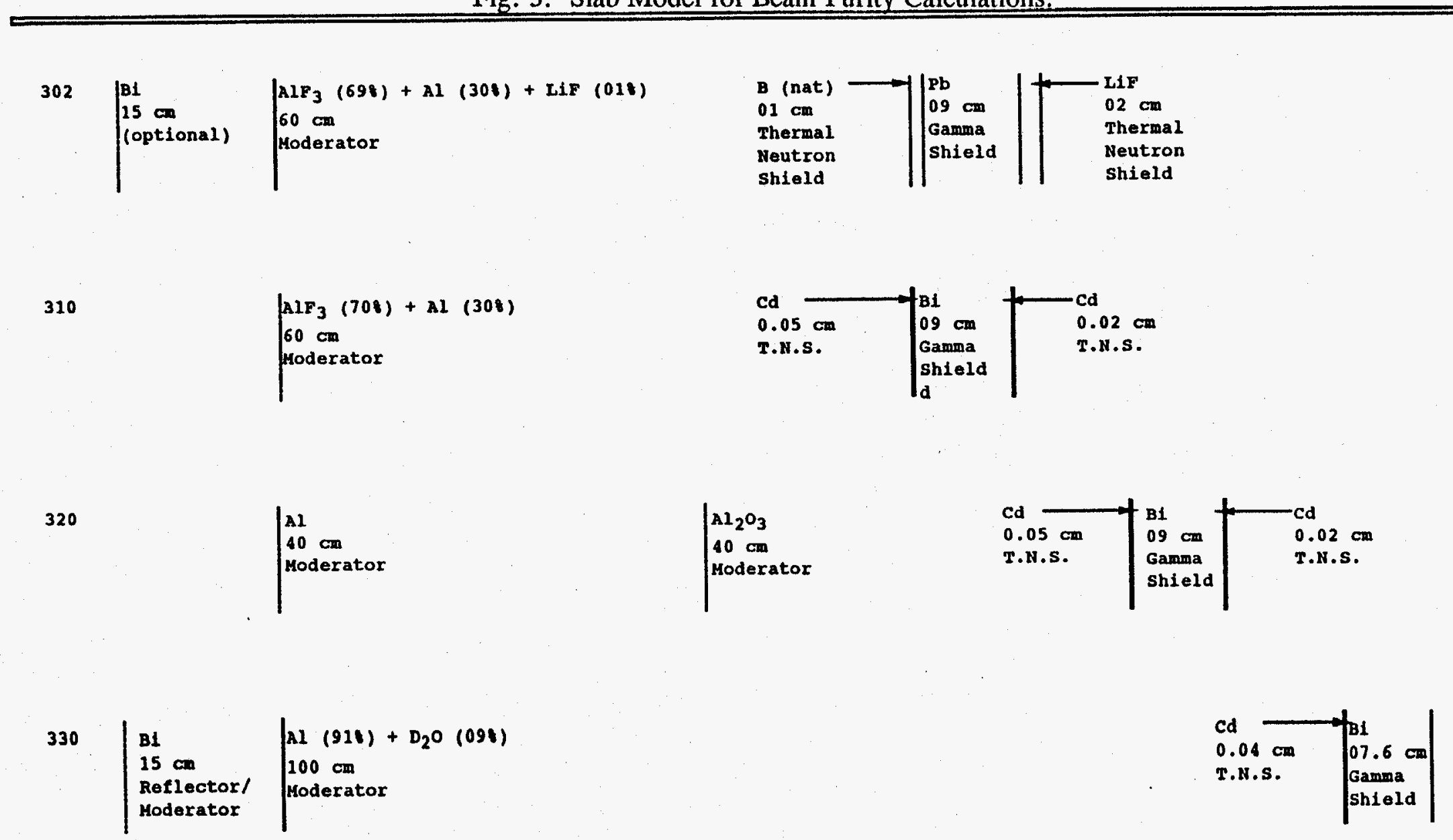

Fig. 4. Slab Filter Designs. 


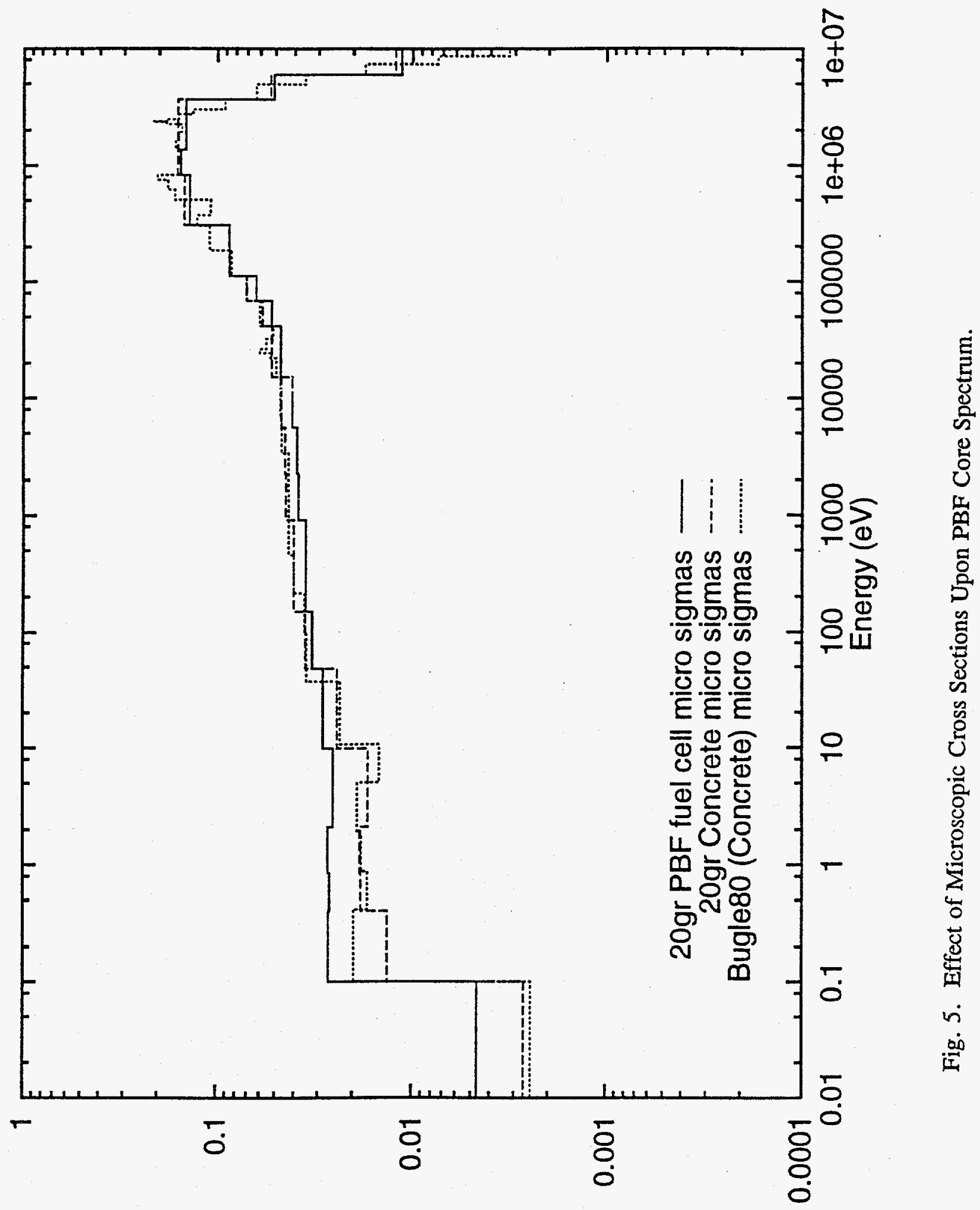

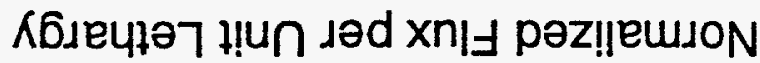




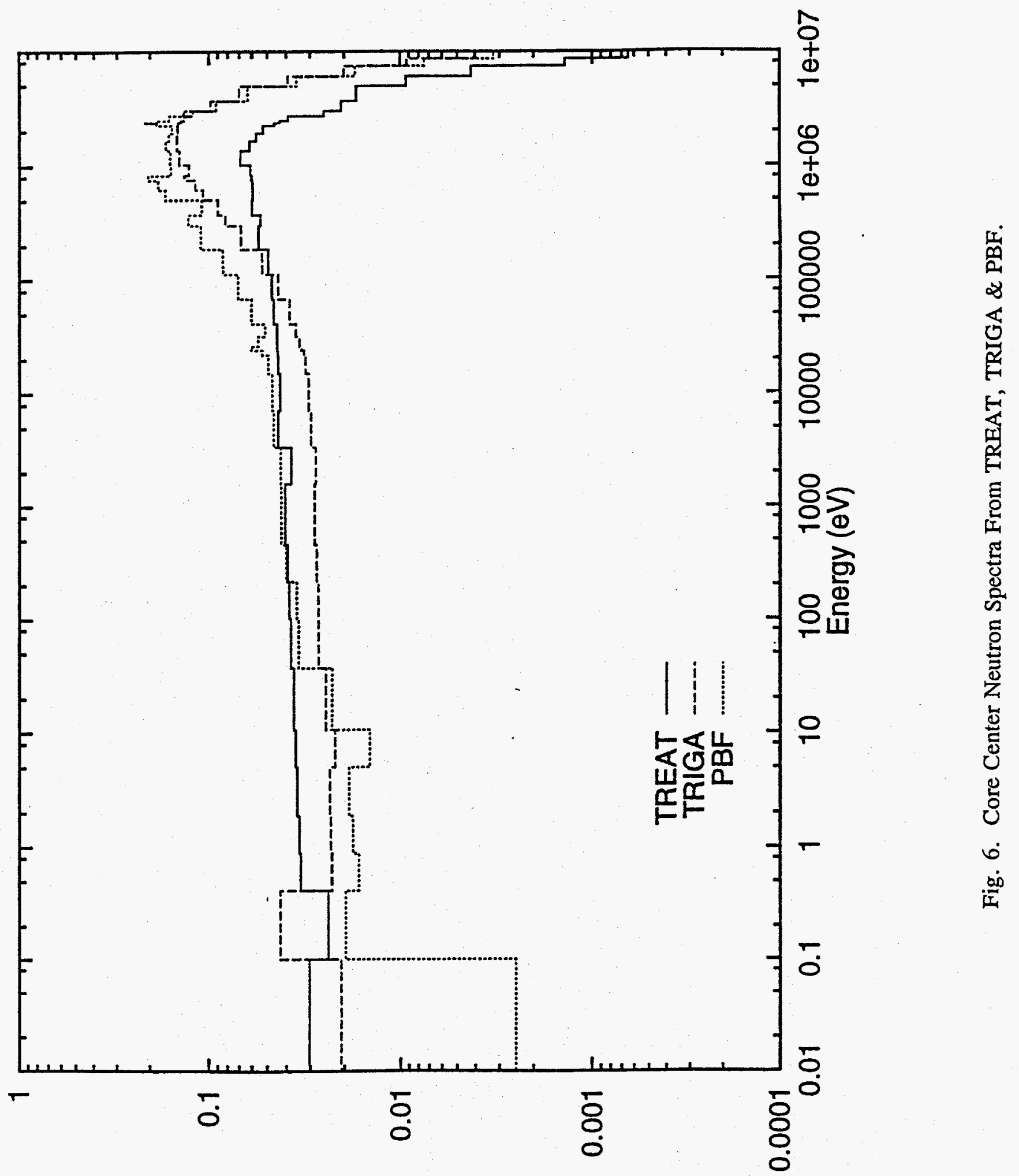

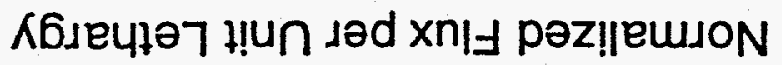




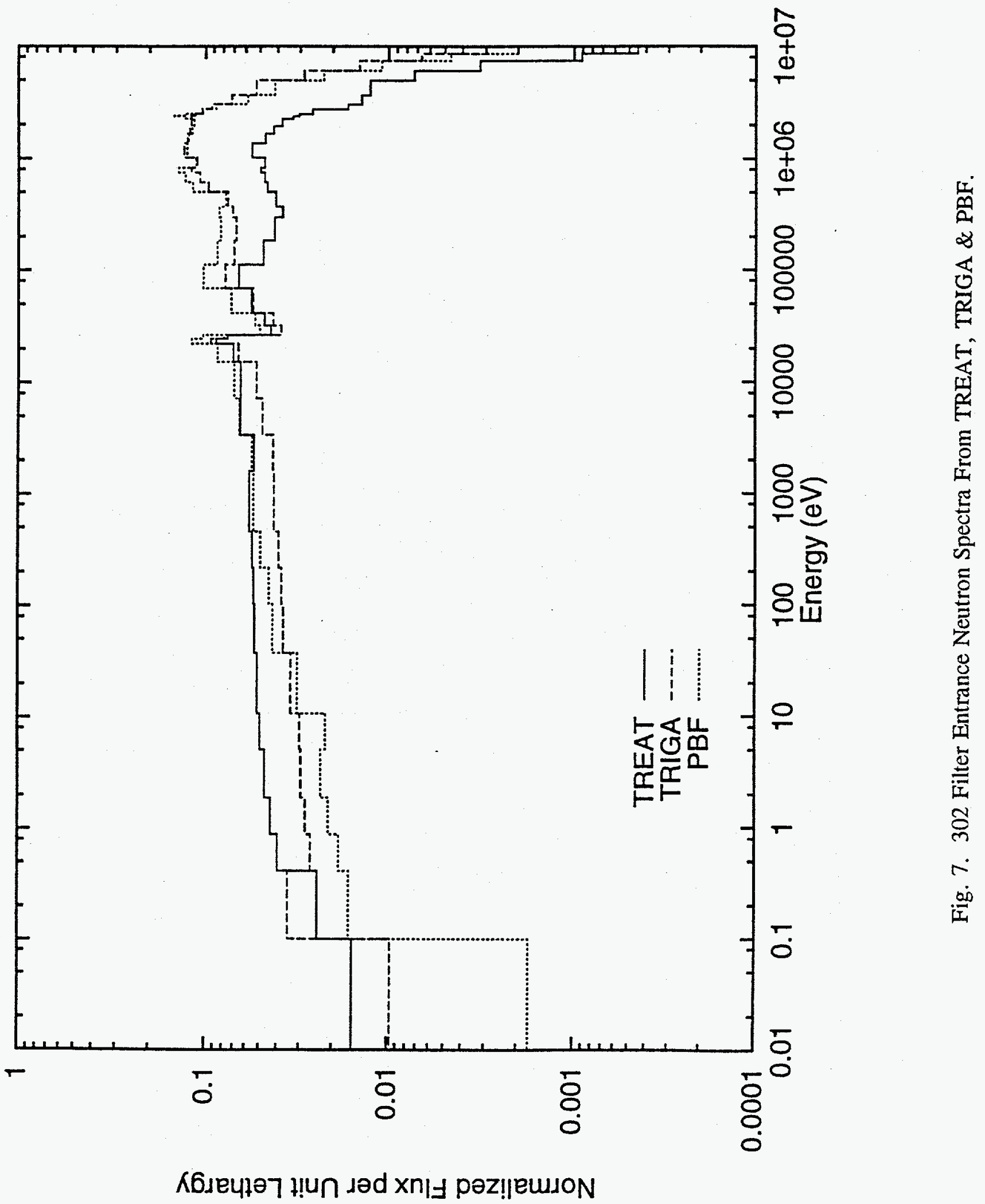




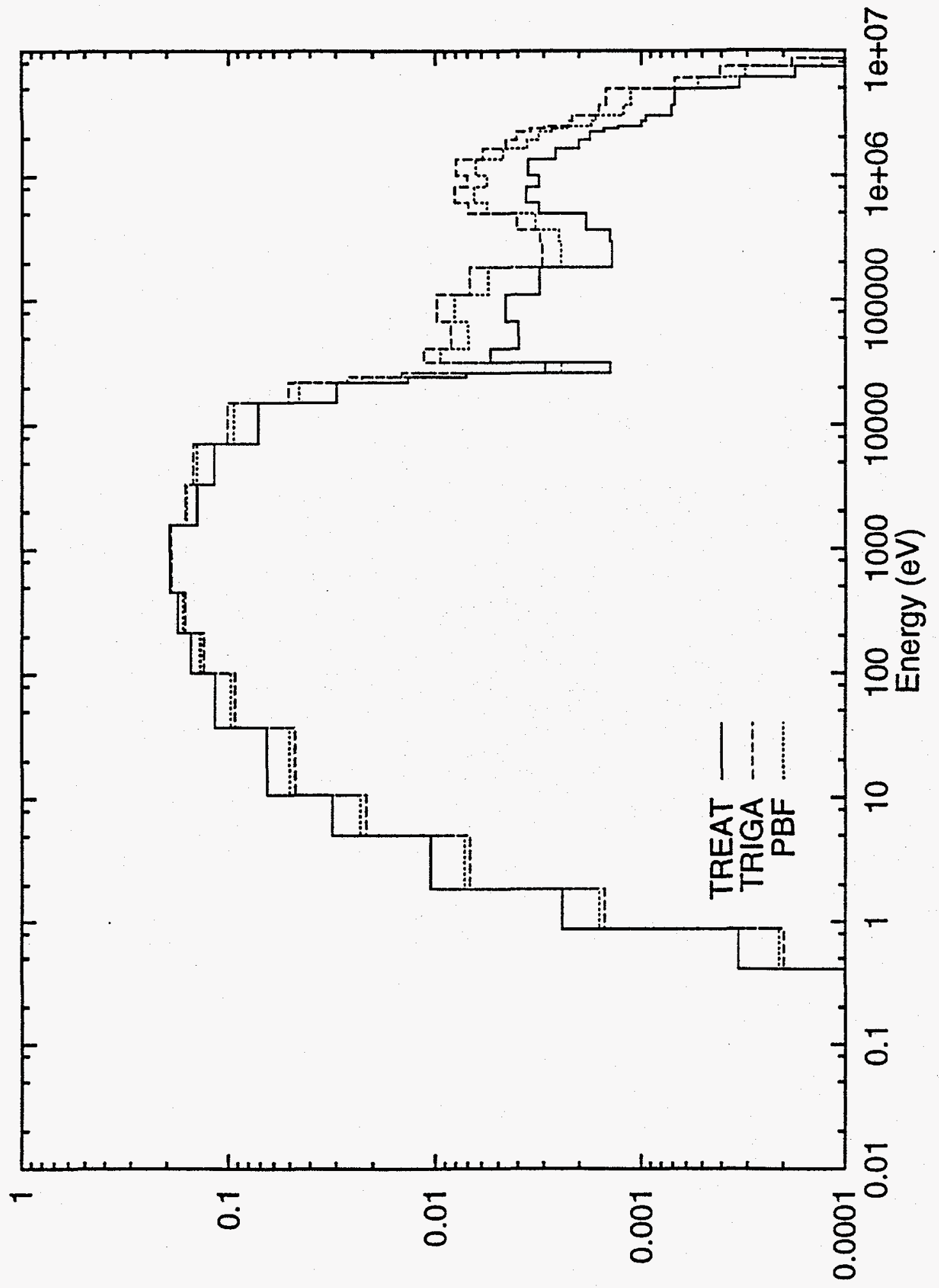


Normalized Flux per Unit Lethargy

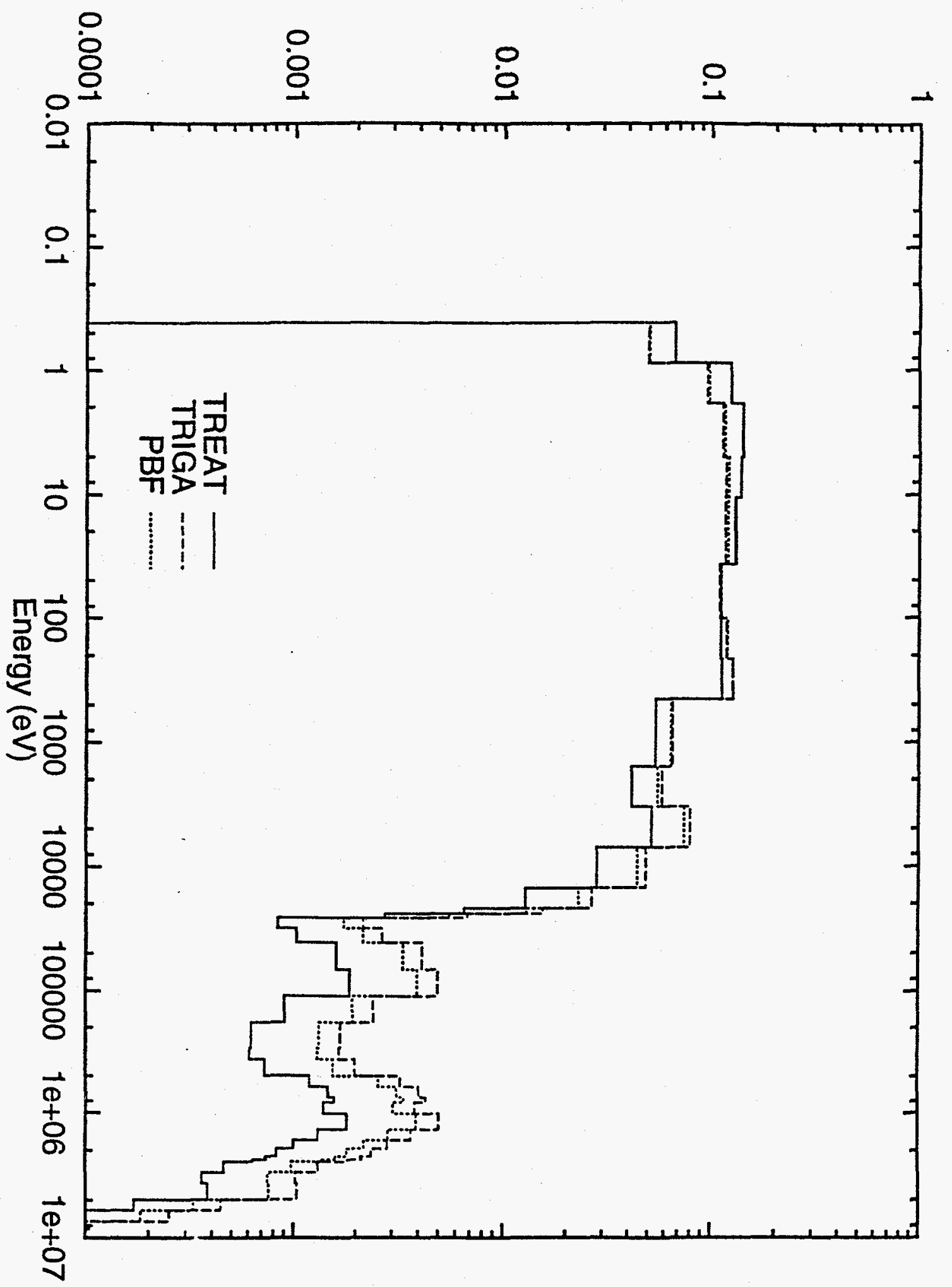




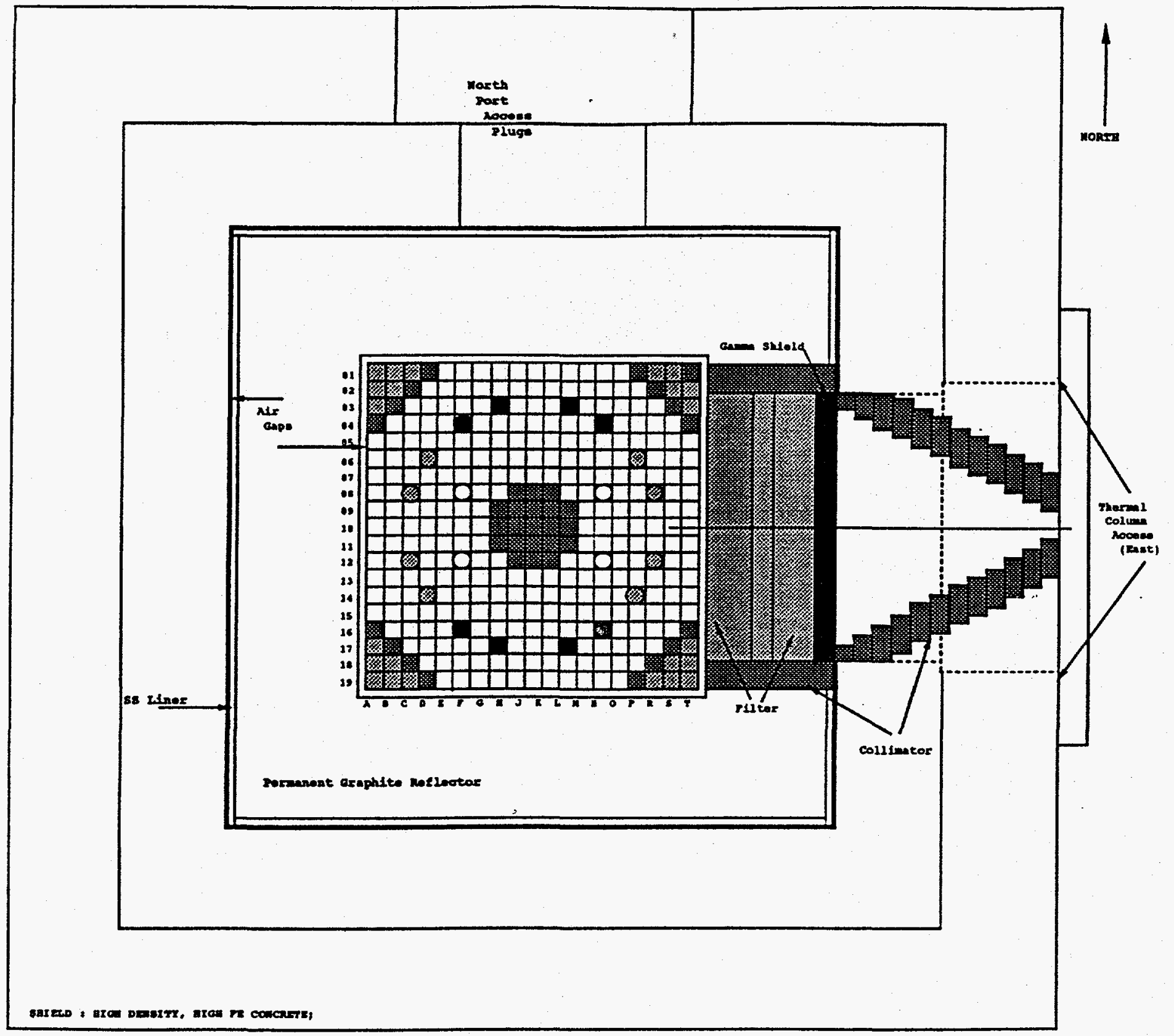

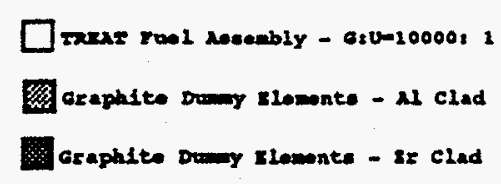

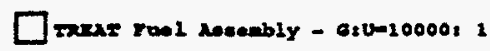

Foraphle drom slownte - Ix clad

Fig. 10. XY Midplane View: TREAT with BNCT Experiment Replacing East Thermal Column. 


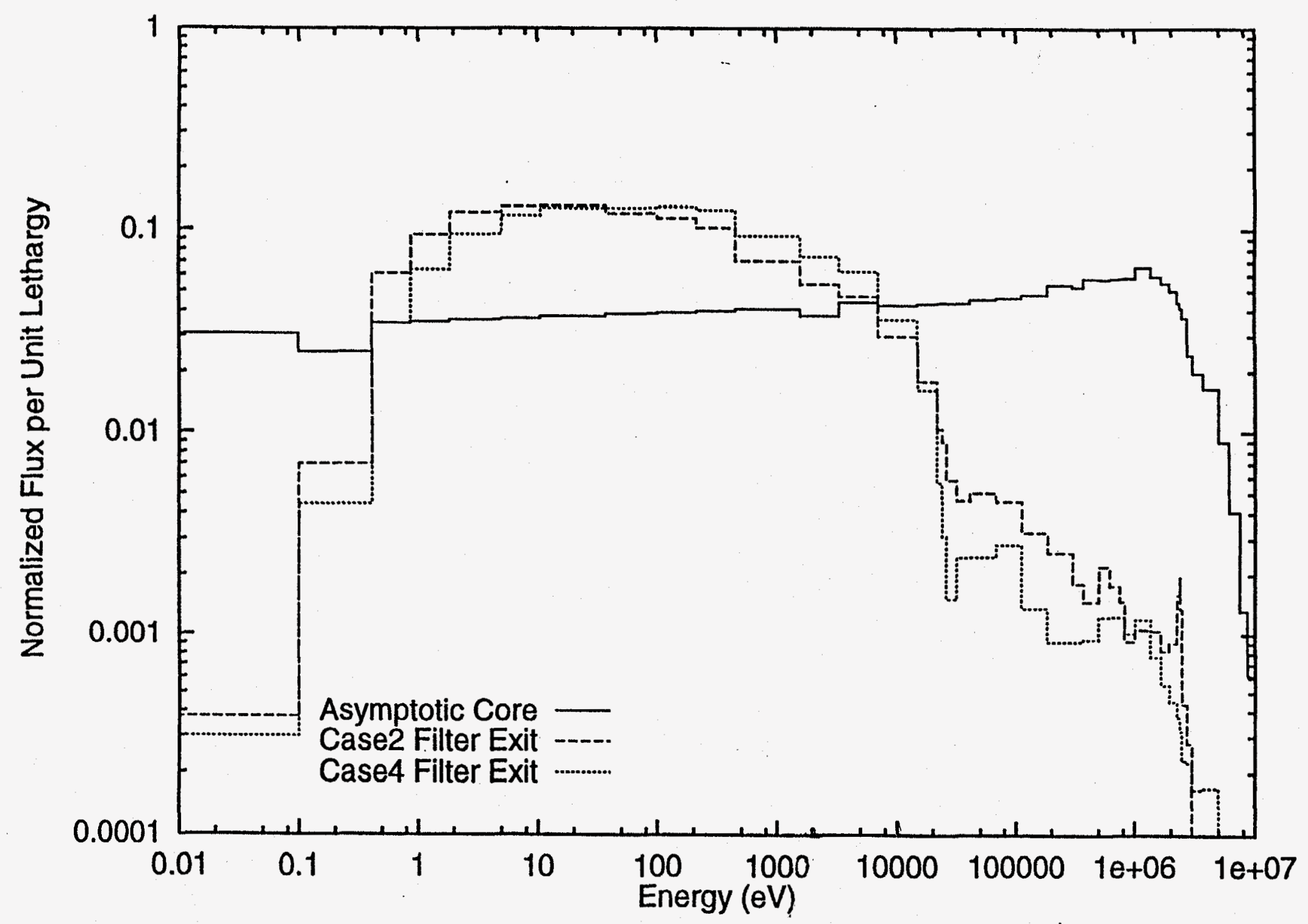

Fig. 11. TREAT Neutron Spectrum Alteration by Two Filters. 


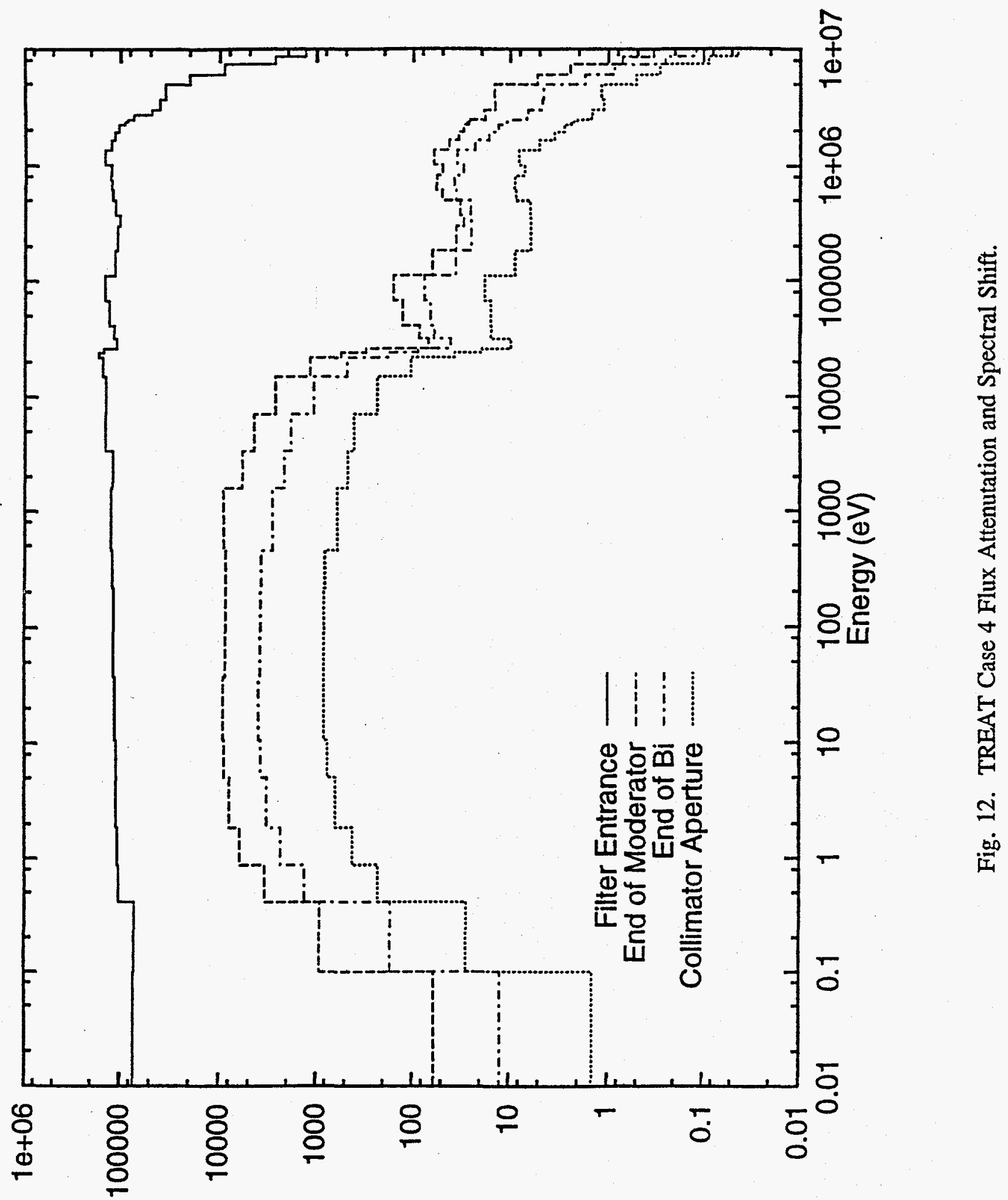

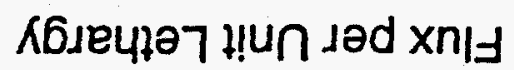




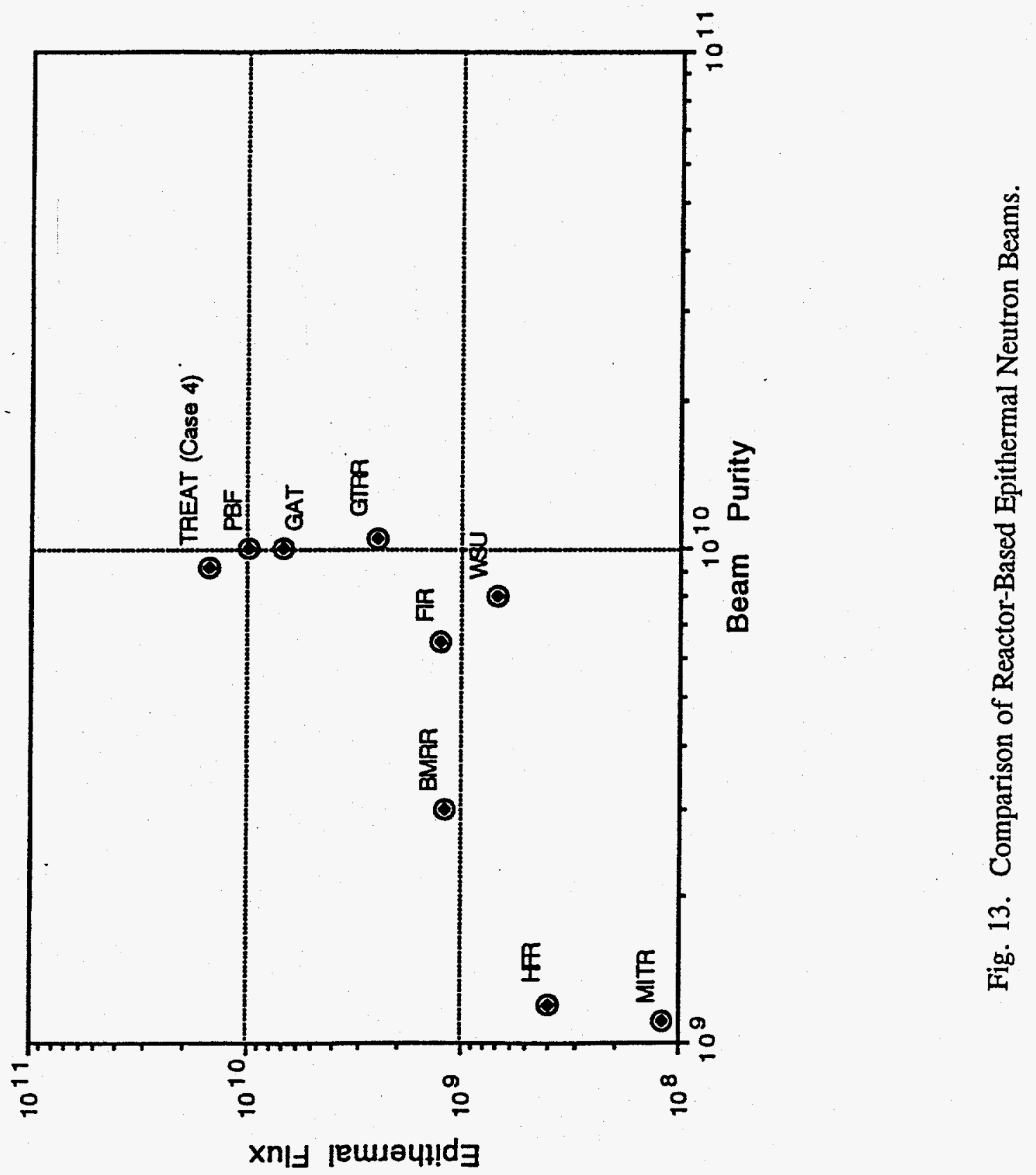




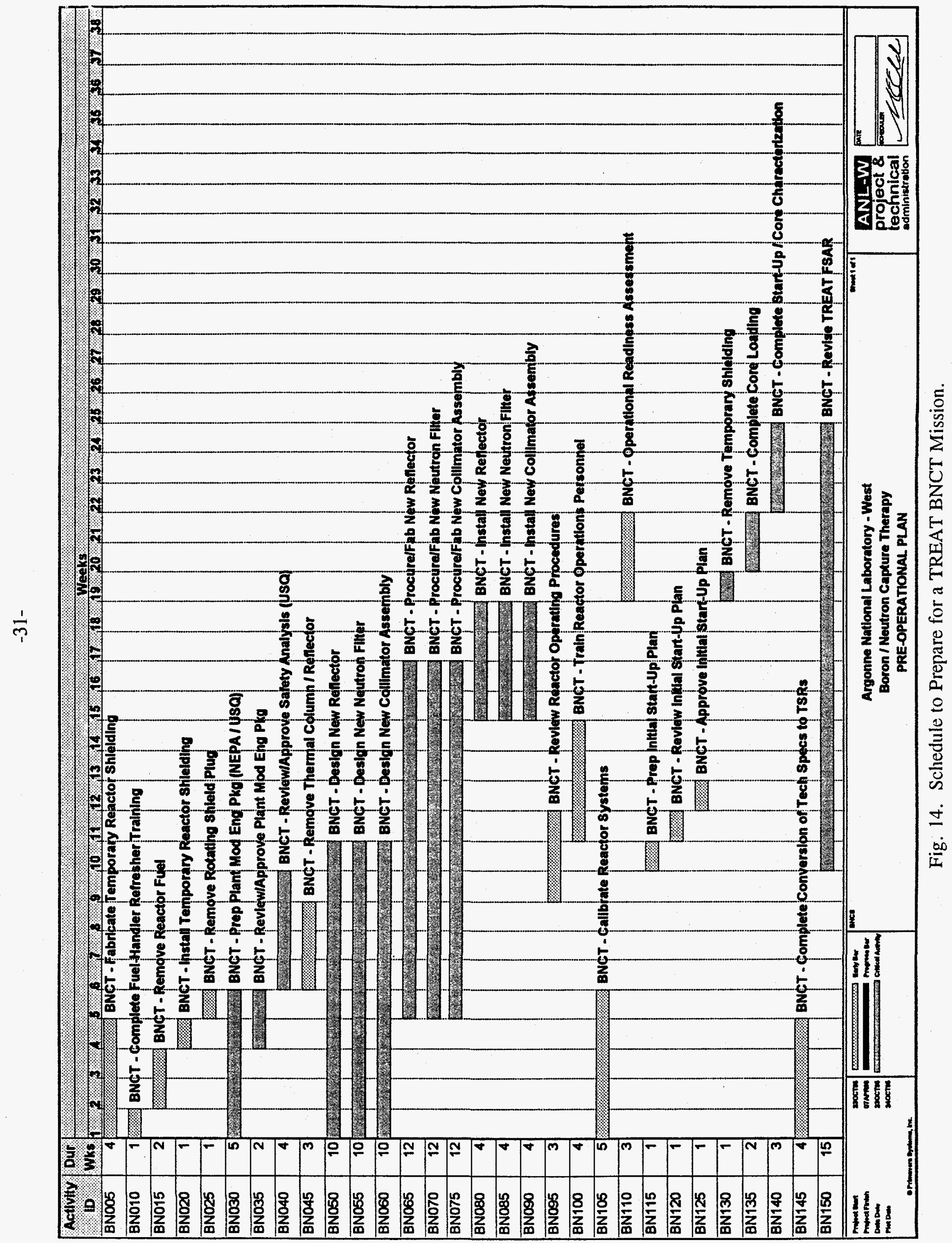




\begin{tabular}{|c|c|c|c|c|c|c|c|}
\hline \multicolumn{6}{|c|}{$\begin{array}{l}\text { COST ESTIMATE FOR PRE-OPERATIONAL PIAN } \\
\text { BORON/NEUTRON CAPTURE THERAPY AT TREAT } \\
\text { BRGONNE NATIONAL LABORATORY - WEST }\end{array}$} & \multicolumn{2}{|c|}{ DATE: $\frac{10 / 24 / 95}{\text { PAGE: } 1 \text { OF } 4 \text { O }}$} \\
\hline \multirow[b]{2}{*}{$\begin{array}{l}\text { ITEM } \\
\text { No. }\end{array}$} & \multirow[b]{2}{*}{ ITEM AND DESCRIPTION } & \multicolumn{3}{|c|}{ MANPOWER COSTS } & \multicolumn{2}{|c|}{ OTHER COSTS } & \multirow[b]{2}{*}{$\begin{array}{r}\text { TOTAL } \\
\text { COST } \\
\end{array}$} \\
\hline & & DISCIPLINE & HOURS & RATE & ITEM & $\cos T$ & \\
\hline \multirow[t]{2}{*}{1.} & \multirow[t]{2}{*}{ FABRICATE TEMPORARY REACTOR SHIELDING. } & ANL-W ENGINEER & 40 & $\$$ \$SO/HR & MATERIALS & $\$ 5,000$ & $\$ 11,500$ \\
\hline & & ANL-W MACHINE SHOP & 100 & $\$ 45 / \mathrm{HR}$ & & & \\
\hline & 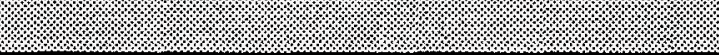 & 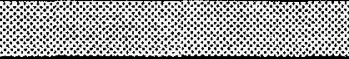 & 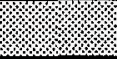 & & & & \\
\hline \multirow[t]{4}{*}{2.} & \multirow[t]{4}{*}{ COMPLETE FUEL-HANDLER REFRESIIER TRAINING. } & ANL-W TRAINER & 40 & S45/HR & & & $\$ 8,400$ \\
\hline & & $\begin{array}{l}\text { ANL-W REACTOR } \\
\text { OPERATOR } \\
\end{array}$ & 80 & S45/HR & & & \\
\hline & & ANL-W SUPERVISOR & 40 & S50/IIR & & & \\
\hline & & $\begin{array}{l}\text { ANL-W SUPERVISOR-IN- } \\
\text { CHARGE }\end{array}$ & 20 & \$50/HR & & & \\
\hline & ?:-1:- & (3.4: & (1): & & 1.. & & \\
\hline \multirow[t]{3}{*}{3.} & \multirow{3}{*}{$\begin{array}{l}\text { REMOVE REACTOR FUEL, INSTALL TEMPORARY } \\
\text { REACTOR SIIIELDING, AND REMOVE ROTATING } \\
\text { SHIELD PLUG. }\end{array}$} & ANL-W FUEL IIANDLER & 80 & $\$ 45 / 1 \mathrm{IR}$ & & & $\$ 5,600$ \\
\hline & & $\begin{array}{l}\text { ANL-W SUPERVISOR-IN- } \\
\text { CHARGE }\end{array}$ & 20 & S50/IIR & & & \\
\hline & & ANL-W ENGINEER & 20 & \$50/HR & & & \\
\hline ?. & & & ; & & & & \\
\hline \multirow[t]{2}{*}{4.} & \multirow{2}{*}{$\begin{array}{l}\text { PREPARE PLANT MODIFICATION ENGINLERING } \\
\text { PACKAGE. MUST INCLUUE NEPA AND USQ } \\
\text { DOCUMENTATION. }\end{array}$} & ANI-W ENGINERR & 400 & $\$ 50 / \mathrm{HIR}$ & & & $\$ 20,000$ \\
\hline & & & & & & & \\
\hline & (4) & & & (2:1: & & & \\
\hline \multirow[t]{2}{*}{5.} & \multirow{2}{*}{$\begin{array}{l}\text { REVIEW AND APPROVAL OF PLANT MODIFICATION } \\
\text { ENGINEERING PACKAGE. }\end{array}$} & ANL-W ENGINEER & 40 & $\$ 50 / \mathrm{HR}$ & & & $\$ 2,000$ \\
\hline & & & & & & & \\
\hline & & \% & & & & & \\
\hline \multirow[t]{2}{*}{6.} & \multirow{2}{*}{$\begin{array}{l}\text { REVIEW AND APPROVAL OF SAFETY ANALYSIS } \\
\text { ASSOCIATED WITII USQS. }\end{array}$} & ANL-W ENGINEER & 40 & \$50/IIR & & & $\$ 2,000$ \\
\hline & & & & & & & \\
\hline & 1). & & & & & & \\
\hline
\end{tabular}




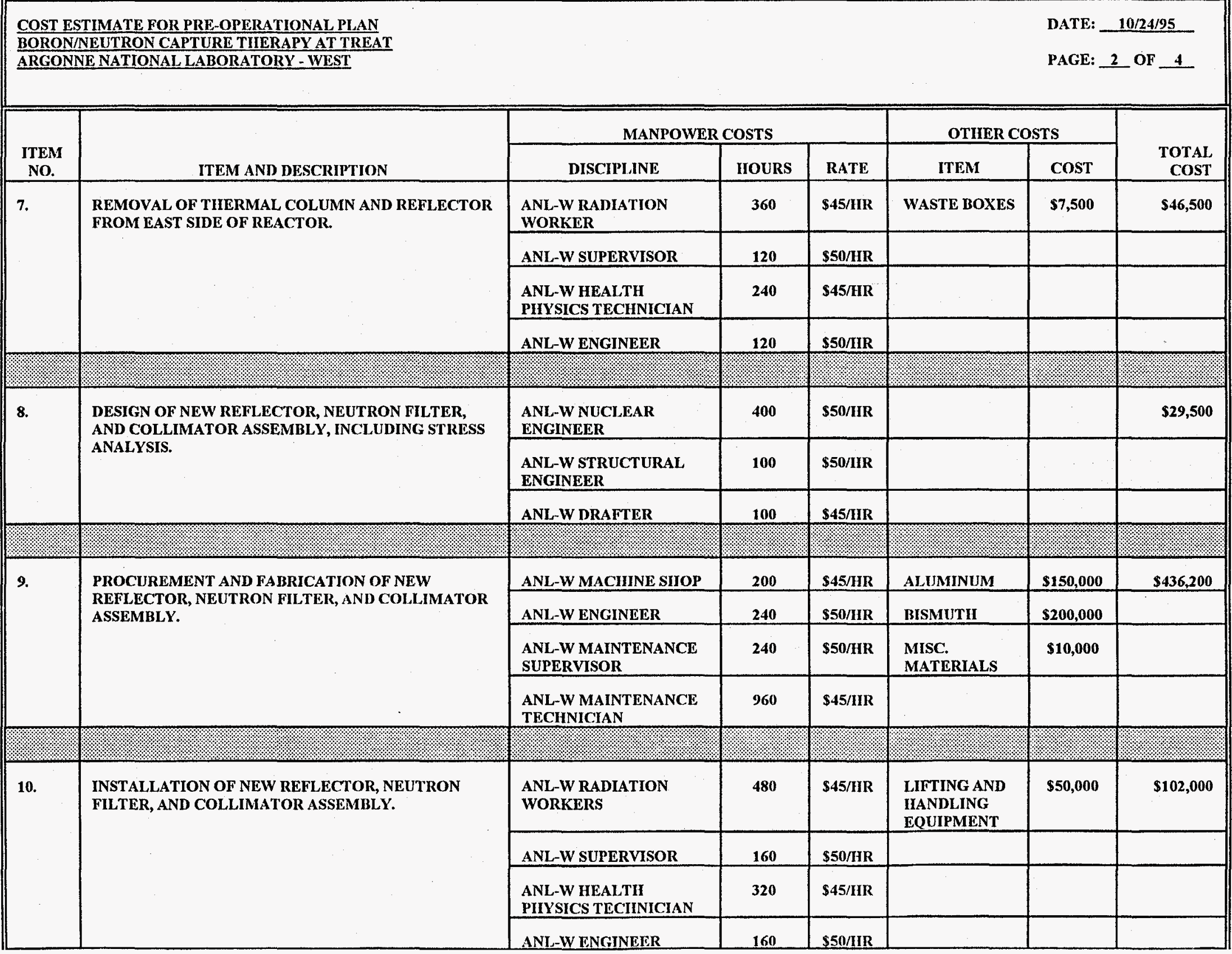











